\title{
Kriz Bağlamında Mekânsal Kaymalar: Kullanıcı Deneyimleri ile Değişen Arayüz Tarifleri
}

\author{
Melis Oğuz ${ }^{1}$ \\ ORCID: 0000-0002-1837-4356
}

\author{
Asli Uzunkaya ${ }^{2}$ \\ ORCID: 0000-0002-4120-7839
}

Öz

Mesken ve meskenin yakın çevresinin fiziksel ve algısal ilişkisine odaklanan bu çalışmada, özel, kamusal mekân ve eylemlerin temas noktaları olan arayüz mekânlara dair kullanıcının deneyimi üzerinden bir okuma yapılmıştır. Bu okuma, disiplinler arası bir etkileşimi, ölçekler arası düşünmeyi ve yöntem karmasını gerektirmiştir. Bu doğrultuda çalışmada, farklı yaş, cinsiyet, hane halkı büyüklüğ̈̈ ve strüktürü, farklı mesken ve yerleşim alanı tipolojilerinde pandemi sürecini deneyimleyen 24 gönüllü katılımo ile derinlemesine görüşmeler yapılmış, katılımcıların görüşmelerde tarif ettikleri mekânsal uyumlanma ve uyarlama örnekleri kendi çektikleri fotoğraflar üzerinden değerlendirilmiştir. Buradan hareketle kullanıcıların pandemi sürecinde mesken ve yakın çevrelerine dair algıları, ihtiyaçları gözlenmiş, özel mekâna sızan kamusal eylemler ve kamusal mekâna taşan özel eylemler için kendilerini uyumlama ve mekânı uyarlama stratejileri anlaşılmaya çalışılmıştır. Kullanıı deneyimlerinden elde edilen veriler, mekânın değişimi ve dönüşümü çerçevesinde incelenmiş, bu doğrultuda meskende gerçekleşen mekânsal kaymalar tespit edilmiştir. Araştırmanın bulguları, kullanıcı deneyimleri üzerinden ihtiyaçları tespit edip bu doğrultuda gereken mekânsal kurguya işaret etmekte, özel ve kamusal eylemsel ve fiziksel kaymaların tariflemesini arayüzler üzerinden yapmakta ve arayüz tasarımının önemine dikkat çekerek bu kavramı mimarlık ve planlama disiplinlerinin birlikte çalışması gereken bir arakesit olarak sunmaktadır.

Anahtar Kelimeler: arayüz, mesken, kamusal mekân, kullanıcı deneyimi, pandemi

\footnotetext{
${ }^{1}$ Dr. Öğr. Üyesi, Beykent Üniversitesi, E-mail: melisoguz@beykent.edu.tr

${ }^{2}$ Dr. Öğr. Üyesi, Beykent Üniversitesi, E-mail: asliuzunkaya@beykent.edu.tr

idealkent (c) Kent Araştırmaları Dergisi (Journal of Urban Studies) 


\title{
Spatial Shifts in the Context of Crisis: Changing Definitions of Interface via User Experiences
}

\author{
Melis Oğuz \\ ORCID: 0000-0002-1837-4356
}

\author{
Aslı Uzunkaya ${ }^{4}$ \\ ORCID: 0000-0002-4120-7839
}

\begin{abstract}
This study focuses on the physical and perceptual relationship and contact between the dwelling and its immediate surrounding. The aim of this study is to analyze user experience for a redefinition of private and public spaces as well as the point of contact of these spaces - the interface. This re-definition requires interdisciplinary interaction, cross-scale thinking and mixedresearch method. Thus, in-depth interviews were conducted with 24 participants differing in their age, gender, household size and structure, dwelling and settlement typologies. The strategies of adapting themselves for the public actions infiltrating into the private space and of adjusting the dwelling for private actions spreading to the public space were evaluated through decoded interviews and the photographs taken by the participants. Analysis revealed spatial shifts regarding public and private in the dwelling and the immediate surrounding. The findings of the research determine the needs based on user experiences and point out to a new spatial setup required to adjust to these needs. The description of private and public shifts through spatial interfaces draws attention to the fact that architecture and urban planning professions have to cooperate in this intersectional scale for the benefit of the cities and its citizens.
\end{abstract}

Keywords: interface, dwelling, public space, user experience, pandemic

\footnotetext{
${ }^{3}$ Assist. Prof. Dr., Beykent University, E-mail: melisoguz@beykent.edu.tr

${ }^{4}$ Assist. Prof. Dr., Beykent University, E-mail: asliuzunkaya@beykent.edu.tr

idealkent @ Kent Araştırmaları Dergisi (Journal of Urban Studies) 


\section{Giriş}

Tarih boyunca salgın hastalıklar, kentlerin ve mimarinin şekillenmesinde büyük rol oynamış, ancak ilk defa COVID-19 pandemisi sürecinde, mesken ve sınırları her şeyiyle salgından korunaklı bir mekân olarak ön plana çıkmıştır. Kamusal mekâna erişimin kısıtlanması sebebiyle eğitim, çalışma gibi zorunlu eylemlerle birlikte sosyalleşme, dinlenme, eğlenme ve spor gibi rekreatif eylemler de meskenin içine taşınmıştır. Minimum varlık felsefesinde, Teige "her yetişkin erkek veya kadın için asgari ancak yeterli, bağımsız, yaşanabilir bir oda" (1932) önerirken aslında konut kıtlığına çözüm getirmeye çalışmaktadır. Bugün ise "asgari ancak yeterli, bağımsız ve yaşanabilir" mekânın fiziksel ölçüleri küçülmekte gibi gözükse de bu mekânlarda gerçekleştirilen eylemlerin çeşitliliği arttı̆̆ için bireyselliğe, mahremiyete ve farklı eylemlerin ardıl ve/veya eş zamanlı gerçekleştirilebilmesine olanak verecek tasarım esnekliğine sahip olması beklenmektedir. Pandemi sürecinde, meskenin bilinegelen anlamdaki mahremiyet içeren barınma niteliğine ek olarak kamusal niteliği de artmıştır. Mesken sınırları içerisinde kimi alanlar hem özel hem kamusal mekâna atfedilen kullanımlara ev sahipliği yapar hale gelmiştir. Bu doğrultuda meskenin içeriye taşınan kamusal eylemler açısından yeterliğinin, fiziksel, işitsel, görsel ve algısal açıdan kamusal olanla ve diş mekânla temasının ve bu temasın kurulduğu alanlar olarak arayüzlerin önemi de artmaktadır.

Mahrem ve özel mekânlar olarak tariflenen meskenin kente eklemlendiği, kamusal mekân ile birleştiği ve kamusallığa -haneye ait olmayana- geçişin sağlandığı bu mekânların, arayüzlerin, biçimlenişi birçok koşula bağlı ve bağımlıdır. Tasarım standartları ve kriterleri, kentsel dinamiklere ve dönemsel eğilim ve akımlara bağlıyken, kullanıcı tarafından anlamsal ve işlevsel olarak da dönüştürülmektedir. Pandemi sürecinde meskende geçirilen zamanın ve gerçekleştirilen eylem çeşitliliğinin artması, özel-kamusal eylem ve mekân çakışmalarına sebebiyet vermektedir. Mekânın, kamusal eyleme olanak sağlaması, kullanıcısının onu bu minvalde kullanabilme/dönüştürebilme imkânına ve derecesine bağlıdır. Kamusallık, içerisinde çeşitli bireylerin ve kamuların iletişime ve ilişkiye geçtikleri bir mekânı işaret etmektedir. Kamusal mekân (public space), ev ve işyerinin özel alanlarının (private sphere) d1şında, insanların bir araya gelebileceği, sosyalleşebileceği ve nispeten düzensiz şekillerde organize olabileceği mekânlar ve yerleri tarif etmektedir (Meyrowitz, 1985; Sennett, 2013). Özel mekânı bunun karşıtı olarak düşündüğümüzde ise, bu çalışmada "ortaklar" olarak tarif edilen, tanımlı kişilerin nispe- 
ten düzenli bir şekilde bir araya geldiği, sosyalleşebildiği ve organize olabildiği mekânlar olarak geniş bir çerçevede tanımlamak mümkün olabilir. Kamusal mekân çalışmalarında kullanılagelen bu geleneksel tariflerdeki bir araya gelme, sosyalleşme ve organize olma kriterleri mekânın kamusal ya da özel olarak kategorize edilmesinde önem arz etmektedir. Bununla birlikte bu araştırmanın gerçekleştirildiği koşullar göz önünde bulundurulduğunda, kullanıcilar ve eylemler üzerinden kamusal ve mahrem ile ilgili yenilenen bir tarifin gerekliliği ortaya çıkmaktadır. Kamusal ve özel eylemlerin mekânsallıklarında ve bu eylemlerin kesişim mekânları olan arayüzlerde kaymalar olduğu ve içerisinden geçilmekte olan koşullar sebebiyle de bu kaymanın devam edeceği düşünülmektedir. Dolayısıyla özele ve kamusala ait eylemsel kaymaların ve bunların gerçekleştiği mekânsallığın tarifinde kullanılabilecek arayüzlerin kullanıc ihtiyacı odağında değerlendirilmesi gerekli görülmektedir. Bu düşünceler doğrultusunda, çalışmanın odağını "mekânsal kaymalar" oluşturmakta, bahsedilen kesişimlerin ve çakışmaların gerçekleştiği "arayüzler" yeniden değerlendirilmektedir. Arayüzü meskenin içerdiği kamusallık bağlamında ve yeni özel-kamusal eylem ve mekân ilişkiselliği üzerinden irdeleyen çalışma, kullanıcı ve mekândaki tepkilerine odaklanan bir eksende kurgulanmıştır. Bu kurguyla,

(1) COVID-19 pandemisi kentlinin özel (mahrem) mekânlar olan ve arayüzler üzerinden kamusal mekân ile etkileşim kurulan mesken ölçeğindeki yaşamına nasıl etki etti?

(2) Kullanıcının mekânsal arayüzlerin oluşumunda ve dönüşümünde rolü nedir?

(3) Deneyimleri ve tepkileri tasarım girdisine dönüşür mü?

şeklindeki sorulara yanıt aranmaktadır. Bu doğrultuda çalışmanın hedefi, (1) meskenin kamusal eylemler açısından yeterliğini sorgulamak, meskenin esnetilemediği ve dönüştürülemediği noktada kullanıcının yaptı̆̆ı uyum ve uyarlamaları tespit ederek mekânsal kaymalara dair çıkarımda bulunmaktır. Bununla birlikte (2) önemli bir karşılaşma-dönüşme ve eklemlenme mekânı olarak arayüzlerin yeterliğini, kullanıc deneyimleri üzerinden analiz ederek gereksinim duyulan özel-kamusal mekân uzanımındaki tasarım kurgusunu detaylandırmaktır.

Bu hedefler doğrultusunda çalışmada öncelikle teorik arka plan olarak mekânsal arayüz kavramı ve kullanıcının rolü üzerinde durulmuştur. Bu teorik çerçeve ile mesken arayüzünün kullanıcı deneyimleri perspektifinden 
yeniden ele alınması gerekliliği ön plana çıkmıştır. Ardından kullanıcı odağında ve karma veri toplama yöntemi kullanılarak araştırma safhası gerçekleştirilmiştir. Katılımcıların özel ve kamusal mekânda gerçekleştirdikleri eylemlere odaklanılmış, kullanıcıların deneyimleri, ihtiyaçları ve kullanıcı ihtiyaçlarından doğan mekânsal müdahaleler analiz edilmiştir. Bulgular aşamasında ise "mevcut/tasarlanmış" hali ile kullanıcıların kendi ihtiyaçlarına göre esnetemedikleri ya da yetersiz kalan mesken ve arayüzünde yaptıkları uyarlama ve(ya) uyumlanmalar tespit edilmiştir. Bu belirlemeler, eylemsellik ve mekânsallık açısından kamusaldan özele istiflenmiştir. Bu doğrultuda tespit edilen mekânsal kaymalar ise kullanım bağlamına göre kategorize edilerek detaylandırılmıştır. Başlangıç aşamasında teorik düzlemde tanımlanan çerçeve, kullanıcı deneyimleri ile rafine edilmiş, izlenimler ve değinilmesi gereken noktalara dair tespitlerde bulunulmuştur. Bu tespitlerle çalışmanın, "s1nır" olarak tariflenegelen ve bu bakış açısıyla tasarlan(a)mayan ya da göz ardı edilen arayüz mekânların kullanıcıların yaşam mekânlarına uyumlanmaları açısından önemine dikkat çekip yeni ve olası mekân kurgularına işaret ederek kentsel ve mimari tasarım literatürüne katkıda bulunacağı düşünülmektedir.

\section{Teorik arka plan: arayüz ve kullanıcı deneyimi}

İnsan yaşamının toplumsal yanlarını ve toplumsal formasyonu anlama ve anlamlandırmanın bir yolu olarak, kamusal alan ve özel alan kavramları ile aralarında yapılan ayrımlar, ana akım yöneticilerin, tasarımcıların ve toplumun yaşamı nasıl gördüğünün ve buna yönelik bu yaşam biçimi için mekânı nasıl kurgulandığının göstergesi olarak düşünülebilir. Özel ve kamusal mekân kurgusunun bir bütünsellik içerisinde ve birbirini besleyen, eksiklerini tamamlayan bir kapsamda yapılması gerekliliğini savunan bu çalışma, bu kurguyu "arayüz" vurgusu üzerinden yorumlamaya çalışmaktadır. Meskenin kamusal eylemler açısından yeterliğine odaklanırken, "kentsel mekân ve konuta da dahil olan, her ikisini de tanımlayan karşılaşma-dönüşme-eklemlenme mekânları"nı mekânsal arayüz olarak değerlendirerek (Oğuz ve Uzunkaya, 2020) sorgulamakta ve yeniden tanımlamaktadır. Teorik eleştiri niteliğinde başlayan bu sorgulama, özellikle pandemi döneminde yaşanan dönüşümlere odaklanmakta ve üç temel nokta çevresinde toplanmaktadır. Bunlar, (1) mekânsal arayüz"ün kamusal mekân ve konuta dahil olan karşılaşma-dönüşme-eklemlenme mekânları olarak daha geniş bir perspektiften ele alınması, (2) özel ve kamusal tanımlarının fiziksel mekânlarla birlikte gerçekleştirilen eylemler üzerinden yeniden düşünülmesi ve (3) bu sorgulama- 
ların konutun kullanıcıları ve onların deneyimleri üzerinden gerçekleştirilmesi gerekliliğidir (Oğuz ve Uzunkaya, 2020). Bu çerçevede teorik düzlemde özel ve kamusal mekânın etkileşimine tekabül eden arayüz kavramına ve kullanıc eylemlerine dayalı deneyim ve geri bildirimlerini ön planda tutan araştırma biçimlerine odaklanılmaktadır (Şekil 1).

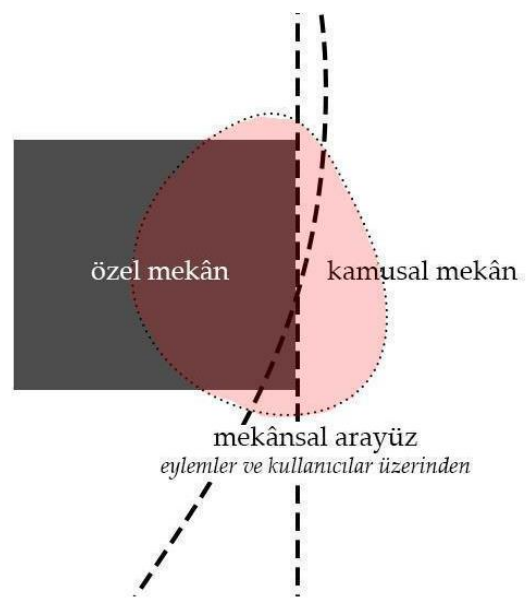

Şekil 1. Kentsel mekân ve konuta da dahil olan, her ikisini de tanımlayan karşılaşma-dönüşme-eklemlenme mekânları olarak arayüz.

Özel ve kamusal mekân arası geçiş alanları (Gehl, 1977) ve bir yapının iç ve dışının buluştuğu kesişme alanları (Sanoff, 1999) olarak ele alınan arayüzler, bu geçiş ve kesişmelerin gerçekleştiği iki alana da aittir. Teorik düzlemde bu kesişmeler bağlamında ele alınırken, mimarlık ve kentsel tasarım pratiğinde çoğu zaman bir sınır niteliğinde görüldüğü, sadece geçiş alanları olarak ele alınmalarının sonucunda da âtıl kaldığı gözlenmektedir. Hâlbuki arayüzler her iki mekâna da aitken, bu mekânların fiziksel ve görsel niteliklerini taşımakta ve birbirlerinden etkilenerek her ikisinin de dönüşümüne olanak sağlamaktadır. Bu bağlamda Porter (2004) arayüzü iki süreç, özne veya güç arasındaki temas noktası olarak tanımlarken, bu iki öğe arasında etkileşimlerin gerçekleştiği bir mekân olduğunu belirtmektedir. Arayüzler bu çalışma kapsamında da iki mekân arasındaki sınırdan ziyade bu mekânlar ve kullanıcıları bağlamında karşılaşmalar, eklemlenmeler ve dönüşmeler üzerinden ele alınmaktadır.

Rekreasyon, eğlence, alışveriş gibi kimi işlevler ve yapı tipleri, belirli kamusal/özel arayüz türleriyle güçlü bir şekilde tanımlanmaktadır (Dovey ve Wood, 2015). Bunlar genel olarak iç mekânlarının kamusal işlevi olan yapılara aittir. Bu çalışma kapsamında, kentlinin gündelik yaşam pratiklerinin 
büyük bir kısmının gerçekleştirildiği mesken de bu çerçevede değerlendirilmektedir. Kamusal alan, açık ve rasyonel tartısmaların yapılabileceği, kamu (devlet, kurumları ve hane dişındaki herkes/her şey) ile hane içi hayat ve ekonomik ilişkilerin özel alanı arasında uzanan bir sosyal alan olarak tariflenir (Benhabib, 1992; Cohen, 1997; Cohen ve Arato, 1992). Bu ayrım, Arendt'in (1994) Antik Yunan'ın özel olan ve agoraya ait olan ayrımından yola çıkan ve Habermas'ın (2003) kamu ile ilgili olan her şeyin eleştirel-rasyonel bir biçimde tartışılmasının söz konusu olduğu kamusal alan tarifi ile örtüşür. Bu şekilde tariflenen kamusal alan, ancak mahrem alanın özgür ve gelişmiş olması oranında özgür olabilecektir. Bu yüzden Liebmann (2004) “kamusal yaşamın ne manaya geldiğini anlamak için, örneğin aile politikası gibi, mahremiyet alanındaki patikaları incelemek zorundasınızdır" der. Bu çalışmada da mahremiyet alanı olan meskendeki değişenler üzerinden kamusal alan ile etkileşime işaret eden arayüzlerin tarifinin de yeniden yapılması gerekliliğine işaret edilmektedir. Meskene ait görülen fiziksel öğeler aslında kentin biçimlenişini ve kamusal yaşantıyı etkilemektedir. Bu arayüz mekânların gerek anlamsal ve eylemsel bağlamı oluşturan öğelerden biri oluşu gerekse de kente açılan ve diğer kentlilerle teması sağlayan uzamsal özellikleri sebebiyle iç mekânı da tanımlaması kaçınılmazdır. Habermas (2003) evin içindeki özel alandan çıkan burjuva çekirdek ailesinin üyelerinin salona geçerek kamusallaştı̆̆ını düşünmektedir. Benzer biçimde meskenin mahrem olmayan, dış ve kamusal kullanım içeren mekânlarla girift bir ilişkide olduğu arayüzler meskenin kamusallaşmaya adım atılan yüzüdür. Arayüz bu bakış açısıyla değerlendirildiğinde hane üyelerinin kentsel açıklıkla, kamusal olan ile ve Negt ve Kluge'nin (2004) tanımı ile "Öffentlichkeit" ${ }^{5}$ ile etkileşime geçtiği mekânsal arakesittir. Meskenin kamusal ile teması ve bu temasın yeterliği günümüz gereksinimleriyle birlikte, özellikle pandemi döneminde sosyal mesafe ile ilgili alınan yönetsel kararlar doğrultusunda konuta taşınan kamusal eylemler çeşitliliğinin artmasıyla daha elzem bir hal almıştır. Bununla birlikte, değişen ve çoğalan mesken içi eylemler nedeniyle mesken, yeni arayüzler de oluşturmaktadır. Pandemi süresince çalışma, eğitim ve sosyalleşme gibi gündelik hayatta kimi istisnai durumlar haricinde gerçekleştirilmeyen işlevlere de mekân olmuştur. Çevrimiçi platformlar, meskenin bir nevi kamusal ekrana ve mekâna dönüşmesine sebebiyet vermiştir. Bu kamusal ekranlar aracil-ğıyla, "biraraya gelen" insanların bileşimi ve büyüklüğü, davranış tarzı, akıl

${ }^{5}$ Açıklık 
yürütme ortamı ve onlara yön veren konular bakımından birbirinden ayrılmakla birlikte, çevrimiçi platformlar aracılı̆̆ıyla fiziksel bir karşılaşma olanağında salonunuzda ağırlamayacağınız katılımcların size ait bir mekâna ve bu mekânda gerçekleştirilen eylemlere eşit bir biçimde katılabildiği görülmektedir. Bu durum, Habermas'ın kamusal alan tarifini çağrıştırmaktadır.

Iveson (2007) "kamusal" veya "özel" bir yeri neyin/hangi standartların oluşturduğuna dair net bir tanım yapmanın, kaçınılmaz olarak kamusallığın ve mahremiyetin mekânsallığına ilişkin araştırmaların kalbinde yatan karmaşıklığın görmezden gelinmesine sebep olacağını belirtmektedir. Kamusal mekân genellikle belirli bir tür "yeri" belirtmek için kullanıldığında topografik bir tanım yapılmakta iken, belirli bir zamanda toplu eylem ve tartışma için kullanıma sunulan herhangi bir mekânı ifade etmek için kullanıldı̆̆ında prosedürel bir yaklaşım sergilenir (Iveson, 2007). Öte yandan, Sheller ve Urry (2003), kamusallık ve mahremiyet ile ilgili kavramsal sınırların "nerede" ve "ne zaman" başlayıp "nerede" ve "ne zaman bittiğine" dair bu karmaşıklığın, durağan topografik tarifler ile çözülemeyeceğini savunurlar. Kamusal ve özel olarak tarif edilegelenler, anlamsal olarak sürekli kaymaya ve mekâna bağlı olarak tanımlanması anlık değişim ve dönüşümlere uğramaya devam etmektedir (Sheller ve Urry, 2003). Bu fizik-mekânsal, psiko-mekânsal, sosyomekânsal tariflerin hem anlamsal hem de işlevsel değişim ve dönüşümünün izlerinin sürülebilmesine dair sağlıklı bir gözlemin ancak bireysel seviyede özel ve kamusal mekânda değişen eylemsel ilişkilenmeler üzerinden yapılabileceği düşünülmektedir. Bu gözlem fiziksel, işitsel veya görsel açıdan yap1lırken bireylerin deneyimleri ve başkalarıyla etkileşimleri de bu yeterliğe etki eden önemli faktörlerdir. Nitekim arayüz, iki boşluk arasında uzanan bir yüzeyken ancak başkalarıyla diyaloğa girdiğimizde oluşmaktadır (Porter, 2004). Böylelikle çalışma, kentliye önce mesken kullanıcısı olarak odaklanmakta ve kullanıcının kendine ait mekânda bireysel uyumlanma ve uyarlamaları üzerinden ilerlemektedir. Kullanıcının meskendeki deneyimine erişmek, mesken çevresindeki kamusal mekâna erişim ve bu mekânların yeterliğine dair veri oluştururken, bir yandan da mekânsal arayüz tasarımına dair dikkat edilmesi gereken hususları göz önüne sermektedir. Bu düşünceler, çalışmayı kullanıcının ve kullanımın odağa alındığı, kullanıcıdan öğrenilenin pratiğe dönüştürülmesini hedefleyen bir çerçeveye götürmektedir.

Literatüre tüketim üzerine yapılan çalışmalarla dahil olan "kullanıcı", mimarlık ve kentsel tasarım alanında nesneler ve mekânla olan etkileşimler üzerinden irdelenmektedir (Mihalache ve Emmons, 2013). Lefebvre (1991) “kul- 
lanıcı"yı kendisine dayatılanları pasif olarak deneyimleyen kişi olarak tanımlar; ancak kullanıc1, aynı zamanda kendisine dayatılanların dönüştürücüsüdür. Kullanımı ile verili-tasarlanmış mekânları dönüştürür. Kullanıma ilişkin detaylı teorik irdeleme, kullanıcılar ve yapılı çevre arasındaki etkileşimlere dair sorgulamalarla yapılabilmektedir (Vardouli, 2015). Kullanıcı ve kullanımdan edinilen fayda, Cupers'a (2013) göre tasarım pratiğinin merkezinde yer alırken, aynı zamanda teori için de gerekli bir kategoridir. Sıklıkla göz ardı edilmekle ve pratik ile bağlanamadıkları ile ilgili eleştirilmekle birlikte, son yıllarda kullanıcılar ve kullanım, tasarım teori ve pratiğinde önemli yer kaplamakta, kullanıcıların gündelik hayat deneyimleri, tasarım çalışmalarına sosyal anlamda yeni sorumluluklar getirmektedir (Cupers, 2013). Bu doğrultuda, kullanıcıyı odağına alan çalışmalar literatürde genel olarak (1) kullanıcının katılımı ile tasarım sürecini değerlendirme (Jones vd., 2005), (2) kullanıcın kentsel karar alma mekânizmalarında rol oynadığı ve kentlinin birebir katıldığı eylemlere odaklanan kentsel sanatsal/performatif çalışmalar (Berg, 2014) ve (3) kullanım sonrası değerlendirmelere (post-occupancy evaluations) (Cooper, 2001; Silva vd., 2017; Zimring ve Reizenstein, 1980) odaklanan çalışmalar olarak ön plana çıkmaktadır.

Kullanım sonrası değerlendirme, mimari tasarımın sistematize edilmesine dair çalışmaların ortaya çıtığ 1960 'lara dayanmaktadır. Tasarlanmış ortamların kullanıcıları için, kişisel ve organizasyonel birçok faktörden oluşabilecek etkinliğin incelenmesini içerirler (Zimring ve Reizenstein, 1980). Bu bağlamda paylaşılan mekânlarda kullanıcıların memnuniyeti üzerine çalışmalar mevcutken, genel örnekler konut üzerinedir. Kullanım sonrası değerlendirmenin en önemli özelliği, ortama müdahale edilememesidir; yani saha başkaları tarafından zaten tasarlama veya kullanma yoluyla manipüle edilmiş alanlardan oluşmaktadır (Zimring ve Reizenstein, 1980). Bu tür çalışmalarda araştırmacı, ortamı tasarlamaktan kaçınarak gözlemlemekte, kaydetmekte ve açıklayarak aktarmaktadır. Bu çalışmanın incelediği mekânlar da zaten hali hazırda tasarlanmış ve kullanılmaktadır. Bu mekânlara müdahale edilmemesi ve tasarlanmış mekâna kullanıcının müdahalesini gözlemleyerek açıkladığı için çalışma, kullanım sonrası değerlendirme kapsamına dahil olmaktadır. Bu doğrultuda, pandemi sürecindeki uyumlanma ve uyarlamalara odaklanırken, çalışmanın temas noktası ve inceleme alanı günümüz meskeni, kullanıcıları ve eylemleridir. Meskenin içine sığmayan eylemlerin arayüze (konut sınırları içinde ve kamusal alan uzamında) nasıl kaydığı ve bu kaymada kullanıcıların rolü anlaşılmaya çalışılmaktadır. 
Tıpkı arayüzün etkileşimle şekillendiği gibi, eylem de insanlar arasında gerçekleşen bir etkinlik olarak insan çoğulluğunu ve çoğulluğun eşitlik ve farklılığına dayalı iki önemli özelliğini barındırır (Arendt, 1994). İnsan, emek harcamadan, herhangi bir iş yapmadan yaşayabilirken, eylemeden yaşayamaz; ancak eylem ile diğer insanlar arasında var olabilir. Kısaca eylem, insanın çoğulluğunun, diğer insanlarla bir arada olabilme olanağının koşuludur (Arendt, 1994). Dolayısıyla etkileşim ve iletişimi gerektiren eylemler sadece toplumsal ilişkiler ile ilgili olmayan, ancak mekânsal içerimleri olan "kamusal alan" ve "özel alan" açısından değerlendirilmesi gereken unsurlardır; zira mutlaka bir mekânda gerçekleşmektedirler. Mekân düzenleyicilerinin, yani uyarlama ve uyumlanma yetisine sahip kullanıcıların, nasıl bir mekân tahayyül ettikleri, buna uygun bir mekânı yaratmalarında ya da yaratma çabalarında görülebilecektir. Cooper'a (2001) göre kullanım sonrası değerlendirme çalışmaları, ileri besleme yoluyla iyileştirmenin bir yolu ve bir geri bildirim yöntemi olarak sürdürülebilir kalkınma için bir kıyaslama yardımı olarak değerlendirilebilir. Burada da esas olan araştırmaciların, pratisyene yön gösterebilecek kullanıcı deneyim, eleştiri ve ihtiyacını açığa çıkarması ve bu mesajın mesleki terminolojiye uyarlandığı bir geçiş aşamasını tasarlamalarıdır. Bu doğrultuda çalışma, araştırmacıların kendileri veya diğer pratisyenler tarafından, kullanıcı odağında yürütülebilecek bir tasarım sürecinin ön aşamasını sunmaktadır. Bu aşama, yani kullanıcının tepkilerinin ölçülmesi ile mekânsal kaymaların tespit edilmesi, güncellenen ihtiyaçları tanımlamaya yardımcı olmakla birlikte günümüz koşullarında arayüzlere dair bir çerçeveyi de çizme çabasındadır.

\section{Araştırma bağlamı ve yöntem ${ }^{6}$}

Kullanıcının mevcut yaşam ritüelleri ve bu ritüelleri gerçekleştirdiği iç-dış mekânlar üzerinden erişemediklerine alternatif olarak mekânı kendisinin düzenlemesi, Alexander'ın (1979) kentler ve yapıların "orada olan/olmaya devam eden olay örüntüleri tarafından belirlenen bir karakteri olduğu" söylemini hatırlatmaktadır. Bu çalışmada da kullanıc ritüelleri ve deneyimleri esas alınmış, mekânsal kaymalara dair bir okuma için oluşturulan araştırma bağlamı, araştırmacı ve katılımcı arasında şeffaflık ve güvenin sağlandığı, ka-

\footnotetext{
6 “Esneyemeyen Meskenler - Yetemeyen Kamusal Alanlar: Kullanıcı Deneyimleri ile Kentsel Arayüzler" başlıklı araştırmaya dayanan bu makalenin akademik çalışmasının uygunluğu Beykent Üniversitesi Sosyal ve Beşeri Bilimler İçin Yayın Etiği Kurulu tarafından değerlendirilmiş ve onaylanmıştır.
} 
tılımcının araştırma kurgusunun bir parçası, şekillendiricisi ve dönüştürücüsü olduğu bir "alan" olarak kurgulanmıştır. Bu bakışla, katılımcılarla gerçekleştirilen derinlemesine görüşmeler aşağıdaki şablon üzerinden derinleştirilmeye çalışılmıştır.

(1) Yaşantıya ve mekân kullanımına dair

(a) Mesken ve kamusal mekân kullanımı: Araştırma soruları, COVID-19 pandemisi öncesinde katılımcının mesken ve kamusal alandaki gündelik yaşam pratikleri, rutinleri ve fizik mekânsal ihtiyaçlarını anlamakla başlar. İhtiyaçları ile örtüşmeyen fiziksel koşulları yorumlayabilmek için meskenin ve yakın çevre kamusal alanın özelliklerinin betimlenmesi istenir.

(b) Eylemler: Katılımcının mesken içi ve dışı eylemlerini ve tercihlerini anlamaya yönelik sorular sorulur. Gündelik yaşam pratiklerinin fiziksel mekâna yansitılan tercihleri ve detayları anlaşılmaya çalışılır. Bu mekânlarda geçirilen süre ve söz konusu mekânların bu ihtiyaçlar ve tercihlere göre nasıl şekillendirilmiş olduğu öğrenilir. Haftaiçi ve haftasonunda değişen rutinler ya da eklenen/ eksiltilen eylemler analiz edilir.

(c) Ortaklar: Meskenden başlayarak (var ise) diğer hane halkı üyelerinin de rutin eylemleri ve bu eylemlerini fizik mekân ile buluşturma biçimleri öğrenilir. Bu, mesken içerisinde eş zamanlı ya da ardıl kullanılan mekânların anlaşılmasını ve pandemi süreci öncesinde de katılımcının uyarlama ve uyumlanma alışkanlıklarını anlamaya yardımcı olur. Meskenin sınırları genişletildiğinde önce yakın komşuluk, ardından yürüme mesafesi sınırları içerisinde bu alanın paylaşıldığı esnaf, kapalı kamusal alanlar ile iliş̧kiler ve yine bu geniş mesafe alanda ortaklar ile kesişme-dönüştürme ve değişme hikayeleri dinlenir. Bu noktadan itibaren bu çalışmada da "arayüz" olarak tarif edilen fizik mekânsal ve algısal ihtiyaç ve tercihlerin gerçekleşme noktaları yorumlanmaya başlanır.

(2) Mekân değişiklikleri, uyumlanma ve uyarlamalara dair

(a) Eylemlerde uyarlamalar/uyumlanmalar: COVID-19 pandemisi ile tarif edilen "yeni normal" süreci, kısıtlamaların daha sıkı olduğu dönemler ve katılımcının aldığı bireysel önlem- 
lerle değişen mesken içi ve dişı gündelik yaşam pratikleri anlaşılmaya çalışılır. Dışarıda yapılan hangi eylemlerin içeri taşındığı, nereye ve nasıl taşındığı sorgulanır. Benzer şekilde pandemi öncesi meskenin kapalı ve mahremiyet seviyesi yüksek mekânlarında gerçekleştirilen hangi eylemlerin arayüze ya da tamamen dışarı taşındığı/taşınmak istendiği anlaşılmaya çalışılır. Bunun için arayüzün algısal tarifinde ne gibi değişiklikler olduğu ya da eylemlerde yapılan uyarlama ve uyumlanmalar çözümlenmeye çalışlır.

(b) Mesken ve kamusal mekân kullanımında uyarlamalar / uyumlanmalar: Mesken içinde ve yakın çevresinde geçirilen zamanın artması ile birlikte, bu mekânlarda gerçekleştirilen eylem çeşitliliği de artmıştır. Aynı mekânın gün içerisinde kaç farklı fonksiyon için nasıl düzenlendiği anlaşılmaya çalışılır. Meskende kullanıcı tarafından ya da verili-tasarlanmış uyarlamalar ile ilgili memnuniyet seviyeleri ölçülür. Yapılmak istenen ya da yapılmış uyarlamalar ile uyarlama yapılamayan ya da uyarlamanın yeterli gelmediği noktalarda kullanıcının mekâna nasıl uyum sağladığı, ne gibi stratejiler geliştirdiği anlaşılmaya çalışılır.

(c) Ortaklar: İçeride ve dışarıda gün içerisinde çok daha fazla kullanıcı eyleminin kesişmesi ve eş zamanlı olarak mekân paylaşımına ihtiyaç duyması, mekânda düzenlemeler yapılması gerekliliğini doğurmaktadır. Katılımcıların bu deneyimleri sorgulanıp hangi mekânların hangi ortaklar ile eş zamanlı/ardıl kullanıldığında ne gibi uyumlanma ve uyarlama stratejileri izlendiği anlaşılmaya çalışılır.

\section{Veri Toplama ve Analiz}

Bu çalışmada Aralık 2020-Ocak 2021 arasında pandemi koşulları gözetilerek etnografik bir araştırma süreci kurgulanmıştır. Araştırmacılar, gönüllü katılımcı arayışları ile ilgili sosyal medya aracılığı ile çağrıya çıkmıştır. Bu çağrı gönüllüler tarafından kartopu yöntemi ile ikincil ve üçüncül çemberlerde yayılıma devam ettirilmiştir. Bunun sonucunda oluşturulan gönüllü katılımcı havuzunda, olabildiğince farklı profilde kullanıcının öncelendiği bir görüşmeci listesi oluşturulmuştur.

Sosyal mesafe ile ilgili alınan bireysel ve toplumsal önlemler gereği katılımcılarla yapılan derinlemesine görüşmeler online platformlar üzerinden 
gerçekleştirilmiş, katılımcıların onamı ile bu görüşmeler kaydedilmiştir. Deşifre metinlerin ${ }^{7}$ okunması sürecinde bir kodlama sistemi geliştirilerek kullanıcıların uyumlanma ve uyarlamalarındaki benzerlikler, farklılıklar, mekânların yeterlilikleri ve yetersizlikleri ile ilgili bulgular kategorize edilmiştir. Deşifre metinler, Türkçe diline özgün bağlaç ve "var, yok, evet, hayır, şey, bir" gibi çok sık kullanılan kelimeler ayıklandıktan sonra, 100'den fazla tekrar edilen kelimelerden oluşan araştırma kelime bulutu oluşturulmuştur. Yukar1daki şablonda aktarılmaya çalışılan araştırma sorusu iskeleti de gözetildiğinde, bu kelime bulutu dahi, kamusal alana aktarılamayan tüm ihtiyaçların "evde" giderilmek durumunda kaldığını açıkça göstermektedir. Kelime bulutunda da görülen önemli ikilemler (içerisi/dışarısı, ev/kamusal alan, önce/sonra gibi) araştırma sürecinde elde edilen belge ve kayıtların analizinde anahtar başlıklar olarak kullanılmış ve bulgular kısmında ortaya çıan ana tespitlerin şekillenmesinde yol gösterici oluşturmuştur (Şekil 2).

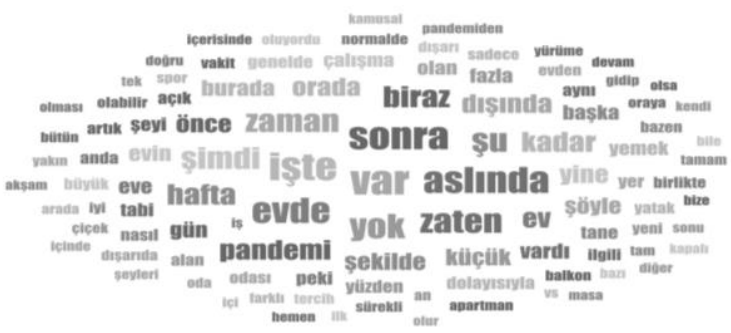

Şekil 2. Araştırma bağlamına dair deşifre metinlerden elde edilen kelime bulutu

Katılımcların mesken ve yakın çevresi ile ilişkilerinin anlaşılmasını gerektiren bu çalışma, çevrimiçi bir medya kullanılarak gerçekleştirildiği için katılımclların anlatılarının nesnelleştirilmesine ihtiyaç duyulmuştur. Bu anlatıların örneklendirilmesi ve belgelenebilmesi için katılımclardan meskenleri ve yakın çevre kamusal alan, bu alanlarla ilişkileri, uyarlamaları ve uyumlanmalarına dair fotoğraflar istenmiştir. Odak grup çalışmalarında olduğu gibi katılımcıların birbirlerinden ilham almaları, ortaya çıan fikirler üzerinden anımsama, olumlama, karşı görüş bildirimi ile tartı̧̧ma konusunu araştırmacıların minimum yönlendirmesiyle derinleştirmeyi hedefleyen araştırma kurgusu, katılımcıların çektikleri fotoğrafların $\mathrm{Mural}^{8}$ üzerindeki panolarda paylaşmaları sayesinde sağlanmıştır. Her bir kullanıcıya, kendisine atfedilen

\footnotetext{
${ }^{7}$ Kayıtlar, İzmir Yüksek Teknoloji Enstitüsü Şehir ve Bölge Planlama Bölümü 3. Sınıf öğrencileri Sevgi Demirel ve Şule Konuk ile Beykent Üniversitesi Mimarlık Bölümü son sınıf öğrencisi Şevval Yalçın'ın değerli katkıları ile deşifre edilmiştir.

${ }^{8}$ Görseller üzerinden işbirliği yapılabilen dijital bir çalışma ortamı.
} 
katılımcı kodu ile kişisel bir pano oluşturulmuştur. Bu panoda katılımcılar kendi çektikleri fotoğraflarını ve isterlerse açıklayıcı notlarını iliştirebilmekte, diğer katılımcıların panolarını da (kimliklerini bilmeden) izleyebilmektedir. Bu izleme durumu, katılımcının daha önce aklına gelmeyen, görüşmede belirtmeyi ihmal ettiği bir durumu anımsamasına ya da başka bir kullanıcı ile benzer bir deneyimi yaşadıysa bunu da panosuna eklemesine olanak tanımaktadır. Bu şekilde araştırma fotoğraf panosu, araştırma katılımcları ve araştırmacılar için sürecin takip edilebildiği bir kamusal alan niteliği de taşımaktadır (Şekil 3).
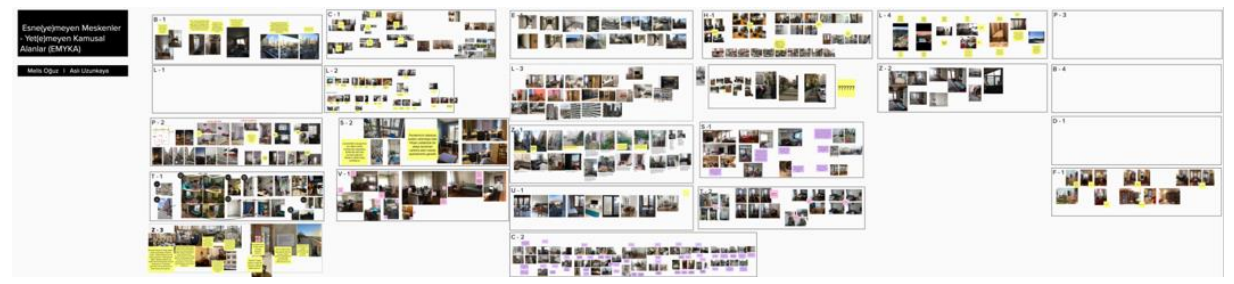

Şekil 3. Katılımcıların erişimine açık araştırma fotoğraf panosu

\section{Katılıme Profili}

Araştırmaya katılım için yapılan açık çağrıya verilen geri dönüşlerde İstanbul'da ikamet eden, pandemi sürecini İstanbul'da deneyimleyen ve 18 yaşından büyük olan gönüllü katılımcılar kabul edilmiştir. Değerlendirilen veriler 24 katılımcıya aittir (Şekil 4).

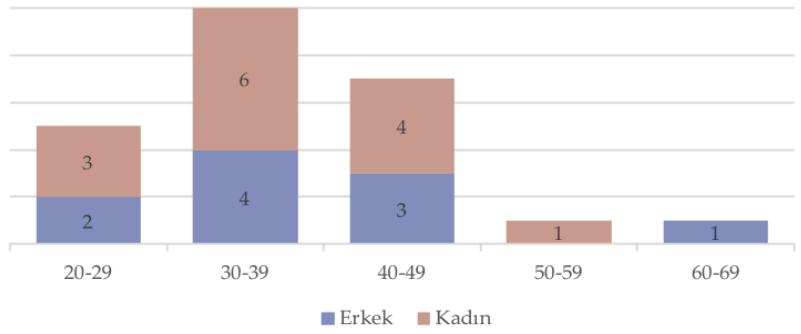

Şekil 4. Yaş ve cinsiyete göre katılımcı sayısı

Katılımcların farklılaşan deneyimlerini anlayabilmek için olabildiğince farklı çeşitlilikte mesken tipolojisi ve yakın çevre morfolojisi örneğinin varlığı, çalışmanın bulgularını daha yansız yapmaktadır. Kullanıcı deneyimini önceleyen bu çalışma hane halkı büyüklüğü, hane halkı strüktürü, yoğunluk, sosyo-kültürel ve sosyo-ekonomik farklılıklar, hane halkı bireylerinin yaş ve cinsiyetleri gibi etkenlerin mesken içindeki yaşam biçimlerini ve mesken ve 
yakın çevresine yönelik deneyimleri farklılaştıran faktörler olduğu esasına dayanmaktadır. Mesken içindeki ortaklar ile kesişmeleri, eş zamanlı ve/veya ardıl mekân kullanımlarını anlamlandırabilmek için farklı yoğunlukta meskenlerin temsili de önem arz etmektedir (Şekil 5).

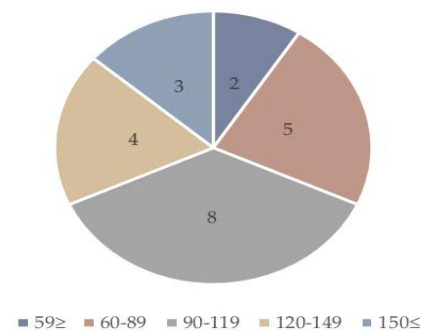

Şekil 5. Mesken büyüklüğüne göre katılımcı sayısı

Görüşmelerde katılımcların uyarlama yapmaları ya da yapamadıkları durumlarda uyumlanma çabalarını etkileyen önemli faktörlerden birisi de ev sahipliği ya da kiracı olma durumu olduğundan, bunun ile ilgili de yine katılımcılarda çeşitlilik sağlanması önemli bir hususu oluşturmaktadır (Şekil 6).

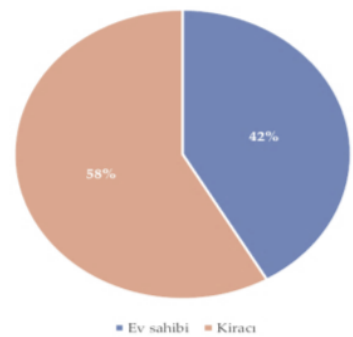

Şekil 6. Ev sahibi ve kiracı olma durumuna göre katılımcı sayısı

\section{Bulgular ve Tartışma: Mekânsal Kaymalar}

Kentsel ve özel mekânın kesişim noktalarında hem tasarlayan hem kullanıcı tarafından göz ardı edilmiş olduğu gözlenen arayüzlerin meskenin yakın dış çevresi ile kurduğu ilişkinin zayıflamasına sebep olduğu gözlenmiştir. Bu zayıflık, kullanıcının özellikle pandemi ile mekânsal, zamansal ve biçimsel olarak değişen gündelik yaşam pratiklerinden ihtiyaçların karşılanamamasına yol açmıştır. İhtiyaçların değişimi, eylemlerin çeşitlenmesiyle birlikte kamusal eylemlerin konut içine kayması, mahremiyetle özdeşleştirilen konut içinin kamusallık seviyesini yükseltmiş̧ir (Oğuz ve Uzunkaya, 2020). 
Katılımclarla yapılan görüşmelerden elde edilen bulgular, üst ölçekten alt ölçeğe doğru, konutun yakın çevresi ve meskenin dış mekânla temas noktalarından başlayarak iç mekâna doğru daralan bir kurgu ile aktarılmıştır. Bu mekânsal kaymalar sıklikla tekrar eden sorun, uyum ve uyarlamalar gözetilerek altı alt başlık altında toplanmıştır. Bunlar:

(1) Dış-bakı / dış-doku: Kamusal mekânla fiziksel ve görsel temasın sağlandığı karşılaşma noktaları

(2) Boşluk tasarımı: Kullanıcının açık alan ihtiyacından doğan verili-tasarlanmıştaki kullanım değişimi

(3) Yakın(sama): Dönüşen dış mekân ve yakın kentsel çevre algısı

(4) Evsel arayüz: Dışarıya atfedilen eylemlerin iç mekânda gerçekleştirilmesinin tercih edildiği kullanım kaymalarına olanak veren arayüz

(5) Kamusal arayüz: İçeriye atfedilen eylemlerin diş mekâna taşarak eylemin kamusallık seviyesinin yükselmesine olanak veren arayüz

(6) Yedek mekânlar: Meskenin fonksiyonel bölümlenmesinde artık kalan, gündelik yaşamsal değeri olmayan ve depolama gibi ihtiyaçların giderilebildiği mekânlar.

Her bir alt başlık özelinde mekânsal kaymaya sebep olan faktörler, kullanıcıların sorun ve/ya ihtiyaçları üzerinden açıklanmış, fotoğraflarla desteklenmiş ve yine kullanıcıların uyumlanma ve uyarlama aktarımları gözetilerek değerlendirmede bulunulmuştur.

\section{Dış-bakı / Dış-doku: Kamusal mekânla karşılaşma}

Pandemi döneminde evde geçirilen zamanın artması, kentin diğer alanlarına erişimin kısıtlanması gibi durumlar sonucunda meskenin yakın çevresiyle kurduğu fiziksel temas ön plana çıkmıştır. Bu alanlar daha önce hızlı kent yaşamı çerçevesinde çoğu kullanıcı tarafından sadece geçiş noktası olarak kullanılırken, bu dönemde kullanıcının hayatında daha önemli rol oynadığı gözlenmiştir. Meskenin sınırları dışında kalan mekânlar ile kurduğu ilişki önem kazanmış, fiziksel ve görsel temas, kullanıcıları kuvvetli biçimde etkileyen bir unsur haline gelmiştir. Bu dönüşüm, kullanıcıların bu mekânlarla tanışmalarını, değerlendirmelerini ve hatta ilerleyen zamanlarda olası konut seçimlerinde önemli bir seçim kıstası olarak tanımlamalarını sağlamıştır. Bu bağlamda, günümüz kentinin temel sorunlarından biri olarak görülen bu temassızlık, kullanıcıların bu mekâna dair farkındalığının ve algısının değişimi sebebiyle mekânsal kaymalar kapsamında ele alınmıştır.

Kullanıcılarla meskenlerinin dış mekânla teması, direkt sokakla temastan, apartman bahçesi, otopark veya site içi açık geçiş alanları ile temasa kadar 
çeşitlenmektedir. Edinilen bu bulgulara göre konutun kamusal mekân ile ilk temas noktalarınının yetersiz olduğu ortaya çıkmaktadır. Dış mekânla görsel ve fiziksel temas, kullanıcıların gündelik hayatını ve iç mekân düzenlemesini de etkilemektedir. Direkt sokağa açılan apartman kapıları, trafik ile karşılaşma, açık alan yetersizliği gibi durumların güvenlik eksikliği ile birlikte aidiyet duygusu yoksunluğuna sebep olduğu gözlenmiştir. Bu arayüzün eksikliği, ana kamusal mekânlarla kurulan ilişkiyi güçleştirmekte, hatta kullanıcının bu "tanımsız mekânları" olabildiğinde "özel araç" ya da ikamesi ile baypas etme ihtiyacı hissetmesine sebep olmaktadır.

Buraya taşındığımızda çeoresi daha çok kötüydü üç yıl önce. Yani şantiyeydi neredeyse, sitenin dışına çıktığınızda şantiyeye çıkar gibi bir ortamla karşılaşıyordunuz. Evimin manzarası hala inşaat yani. Karşımda kocaman bir bina, başka, B blok, sitenin başka bir bloğu var. ... Burası çamur çaylaktı biz ilk buraya taşındığııızda ve ben metrobüse on dakika yürümek zorunda kalıyordum. Böyle işe gittiğimde paçalarım çamur oluyordu. İşe gittiğimde ilk bir tuvalete giriyordum. Paçalarımı falan temizliyordum. Ondan sonra masama geçiyordum. Şimdi biraz daha toparlandım. Bir de erkek arkadaşımla saatlerimiz biraz daha uymaya başladı. Onun arabası var, metrobüse sabahlar burakmaya başladı. Yani ve daha açık konuşmak gerekirse taksiye binmeye başladım. Yani kısa mesafe ücreti yazıyor. İşte haftanın iki günü falan taksiye binip metrobüse gidiyorum. Haftann ü̧̈ günü falan da erkek arkadaşım bırakıyor ofise gittiğimde. Ona resmen bütçe ayırdım diyebilirim yani açık konuşmak gerekirse. Ya olacak gibi değildi, bir yıl bir buçuk yıl falan yürüdüm, kışta kıyamette. Bazen sırllsıklam falan gidiyordum ofise ama olacak gibi değildi artık. Sonra dedim ki buna bir bütçe ayırayım... (Katılımcı L-3, Kadın, 30)

Dış-dokunun fiziksel olarak daha tanımlı olduğu, yakın çevre sosyal ve ekonomik ilişkileri ile bu bağlamın kuvvetlendiği eski mahallelerde ihtiyaçların yakın çevrede görülebilir olması, fiziksel ve sosyal çevre ile tanışıklık seviyesinin artmasına, yürüme ile erişim alanlarının ve aidiyet duygusunun daha geniş bir çapa esnetilmesine ön ayak olan ve katılımclların gündelik hayat pratiklerinde faydalı ve olumlu gördüklerini belirttikleri özelliklerdir.

Buradaki şey hikayesi güzel; aşă̆ıdaki yerleri çalıştıran çoğu insan da burada yaşıyor, aslında hem komşum hem de aşağıda mekânları var. Bir de bu güzel bir şey aslinda. Yani ben çok beceremedim onu, burada çok vakit geçirmediğim için ama özellikle burada yaşayan benim arkadaşlarım var, burada o komşuluk bağlar ve ilişkiler anlamında birbirleriyle çok fazla görüşüyorlar. Benim o kadar değil. Yani buradan çıkmadan hayatınızı çok rahat götürebilirsiniz. (Katılımcı Z-1, Kadın, 43) 

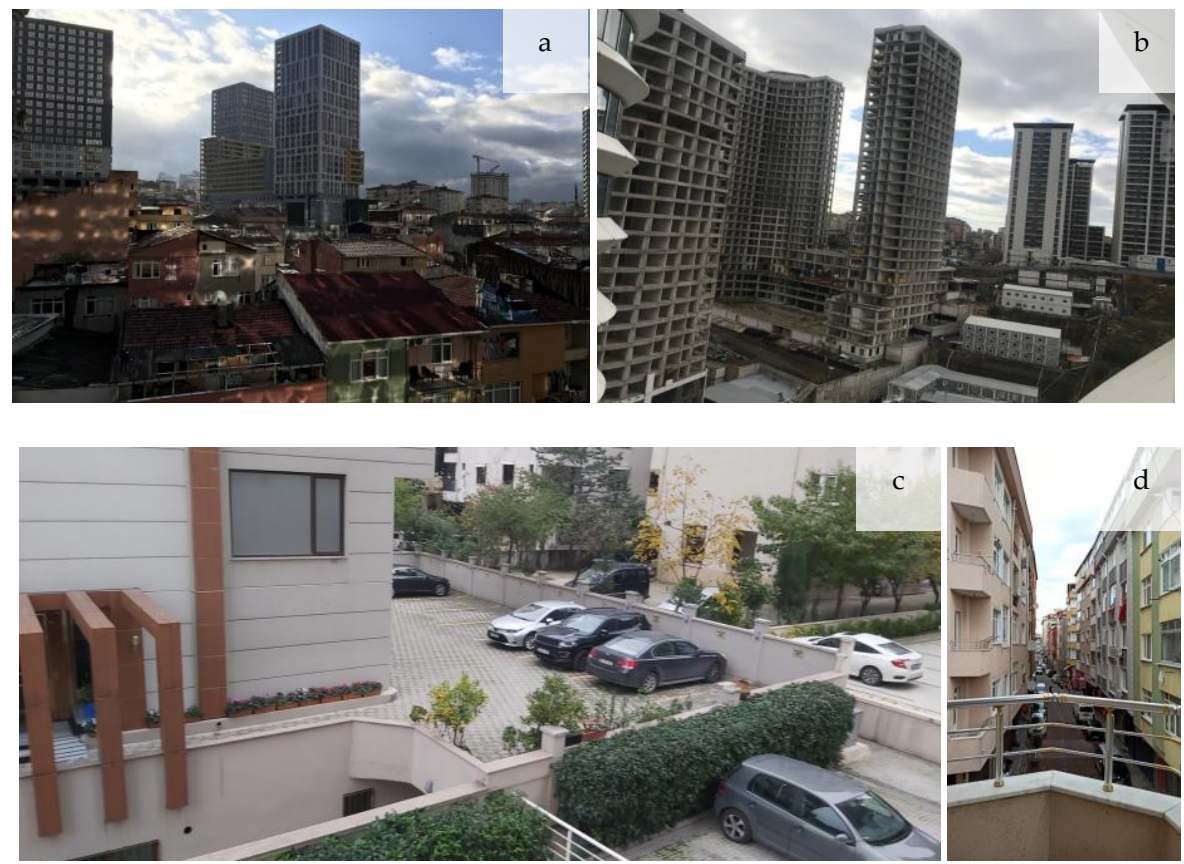

Şekil 7. Bağlam: Sokağın karmaşası, diğer yakın cepheler, düzensiz yapılı çevre, otopark. ${ }^{9}$

Meskenin yakın çevresi ile kurulan bu ilişkinin belirleyicileri olan fiziksel birleşim noktaları olan sınırlar ve geçişler (pencere ve balkon gibi şeffaf açıklıklar) ve bu açıklıklardan görsel temasın sağlandığı bakı noktalarının şekillenmesinde yerleşim biriminin morfolojik yapısı da önemlidir. Bu yapı, kullanıcı algısını şekillendiren, neyin içeri, neyin dışarı ait olduğu ile ilgili kodlanmanın pekiştirildiği anlambilimsel bir deneyim sürecinin de başlangıç noktasını oluşturur (Şekil 7).

Mesken sınırları içerisinde geçirilen zamanın artması ile dış dünyada neler olup bittiğinin izlenebildiği, kullanım hakkı kendisinde olmasa dahi yeşil ve doğa ile fiziksel ya da görsel ilişkinin önemi, kullanıcılar tarafından vurgulanmaktadır (Şekil 8).

Giriş kapım direkt olarak sokakla bağlantllt. pandemide küçük bir bahçe yarattım bu durum balkonum olmadığ için, sandalyemi buraya koyup sokă̆a çıkma yasaklarnnda açı havada oturabildim. Bu alan, öncesinde de depremden korkan biri olarak böyle bir geçirgenlik, bana iyi hissettirdi. (Katılımc1, Z-1, Kadın, 43)

\footnotetext{
9 a: Katılımcı E-1, Erkek, 47, Salondan dış-bakı b: Katılımcı L-3, Kadın, 30, Dış-doku c: Katılımcı C-1, Kadın, 42, Çalışma odasından diş-bakı d: Katııımcı P-2, Kadın, 27, Yatak odasından dış-bakı
} 

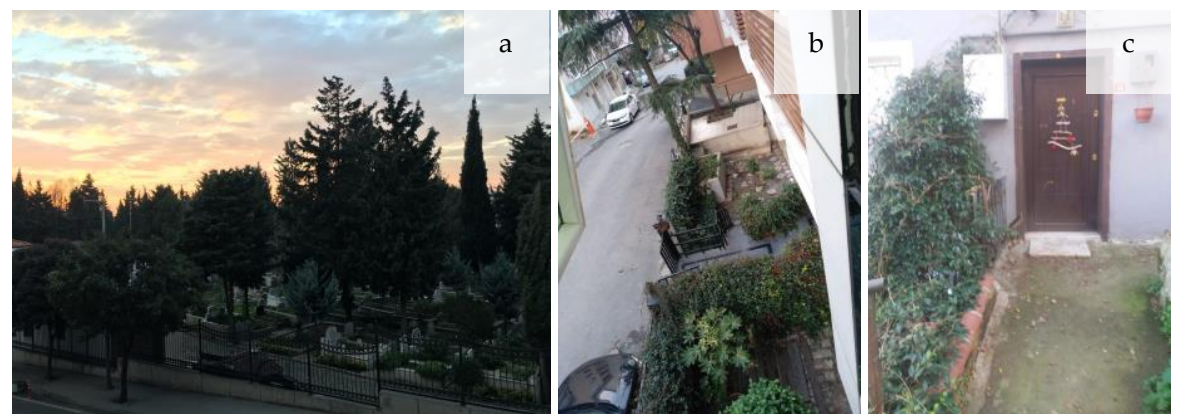

Şekil 8. Yakın çevrede açık alan ihtiyacını karşılayan farklı yeşil alan kullanımları. ${ }^{10}$

Fiziksel ve görsel bu temasın olumlu veya olumsuz algılanışı ve deneyimlenmesi iç mekân düzenlemesini de etkilemektedir. Doğa ile ilişkili veya tanımlı ve aidiyet duygusunu pekiştiren bir kamusal mekân dış-bakısı olan kullanıcılar iç mekânda daha rahat bir kullanıma sahip olduklarını belirtmişlerdir. Dış-doku ya da dış-bakıda göz ardı edilmek istenen, iç mekân ve dış mekân ilişkisinin kesilmek istendiği durumlarda ise kullanıcılar bu geçiş noktalarını bilinçli olarak geçici/kalıcı seperatörlerle içeriye dahil etmiş ya da organik doku ile dekore ederek görsel temasta ihtiyaçlarını karşılamaya çalışmiştır (Şekil 9).

Pencerelerin önleri hem iç hem de dış mekânlar daha önce boşken pandemi sürecinde saksı bitkileri ile doldu. Dış mekânda daha çok yenilebilir bitkiler yetiştirdim. Mutfakta da bu yetiştirdiklerimi kullanmaya devam ediyorum. (Katılımc1, Z-1, Kadin, 43) (Şekil 9b)

Yani balkona bir anda çıktığınızda hemen çat diye karşınızda birini görebiliyordunuz. O yüzden çok hoşlanmıyordum ama zaten çok ihtiyaç da duymuyordum çünkü evde çok fazla zaman geçirmiyorduk. ... Haftanın bir günü evdeyim, onda da zaten çamaşırın, bulaşı̆̆ın, mutfağın, ödevin ya da işte film izliyorsun, dizi izliyorsun çok fazla balkon kullanma ihtiyacı hissetmiyordum. Ama pandemi sürecinde sürekli evde olunca ve aslında biraz da yalnız olmanın da etkisiyle çok farklı mekânlarda çok farklı şeyler yapma ihtiyacı hissediyor oldum. ... Balkonda şöyle bir şey yaptım; dediğim gibi yandaki binayla çok yakın olmakla birlikte onların hemen terastan doğrudan bizim balkon görünebiliyor ve çok yakın bir temas. Ben de kendimce şöyle bir çözüm buldum, aslında ilk etapta bu çözümü balkonu kullanmak gibi değil de o içerideki yazın çok sıcak

\footnotetext{
10 a: Katılımcı T-1, Kadın, 28, Balkondan dış-bakı - mezarlık

b: Katılımcı, T-2, Erkek, 26, Salondan dış-bakı - apartmana ait ancak tek bir daire sakini tarafından kullanılan/düzenlenen bahçe

c: Katılımcı, Z-1, Kadın, 43, Daire dış kapısından dış-doku
} 
basmasından ötürü o balkon kapısını açarak hani o hava sirkülasyonunu, serinliği sağlamak için aslında yapmıştım. Sonra şeyi fark ettim, ben masamda oturuyorum balkon kapısı açık hemen böyle karşımda ve karşı terasa biri çıktığında biz göz göze geliyoruz. Ilk önce bu beni rahatsız etti zaten. Sonra şöyle bir şey yaptım, bu renk, büyükçe bir çarşafi bir üstteki tellere, bir de o öndeki tellere bağlayarak kendime bir seperatör aslında yaptım. $O$ çarşafın o aralardan hava akışı sağlanıyordu ama ben doğrudan karşı tarafi görmüyorum, onlar beni görmüyor oluyordu. (Katılımc1, P-2, Kadın, 27) (Şekil 9c)
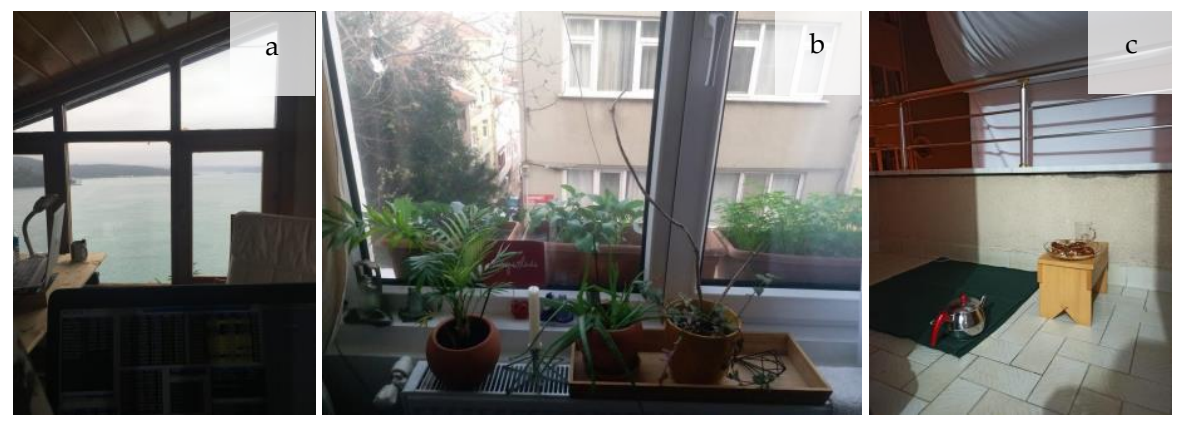

Şekil 9. Konut içinden dış mekânla kurulan görsel temas: mevcudun yeterliliği ve uyarlamalar. ${ }^{11}$

Kullanıcıların aktardıkları üzerinden dış-bakı ve dış-dokunun önemi ortaya çıkmakta, bu tür bir arayüz eksikliği algısal boyutta kullanıcının iç mekân kullanımı ve düzenlemesini ya da dış mekânla ilişki/ilişkisizlik durumunu etkilemektedir. Böylelikle mahremiyet ile ilgili ihtiyaçlar da gözetilerek bu dış-bakı ve dış-doku noktalarının tasarımına dikkat edilmesi gerekliliği ön plana çıkmaktadır.

\section{Boşluk tasarımı: Kullanıcının açık alan ihtiyacından doğan verili- tasarlanmıştaki kullanım değişimi}

COVID-19 pandemi süresinde meskende geçirilen zaman artmış, çalışma, sosyalleşme gibi tüm eylemler içeriye taşındığ 1 için katılımcıların dış mekâna ve açık alana olan ihtiyaçları da meskenin "boşluk" arayüzleri ve yakın çevresiyle temas noktalarına taşınmıştır. Balkon ve bahçe kullanımına sahip kullanıcılar kendilerini bu dönem özelinde görece şanslı hissetmektedir (Şekil 10).

\footnotetext{
11 a: Katılımcı Z-2, Kadın, 35, Çalışma alanının dış-bakıya göre konumlandırılışı b: Katılımcı, Z-1, Kadın, 43, Dış-bakı olumlama düzenlemesi c: Katılımcı, P-2, Kadın, 27, Balkonun dış-bakısını sınırlayan perdeleme
} 

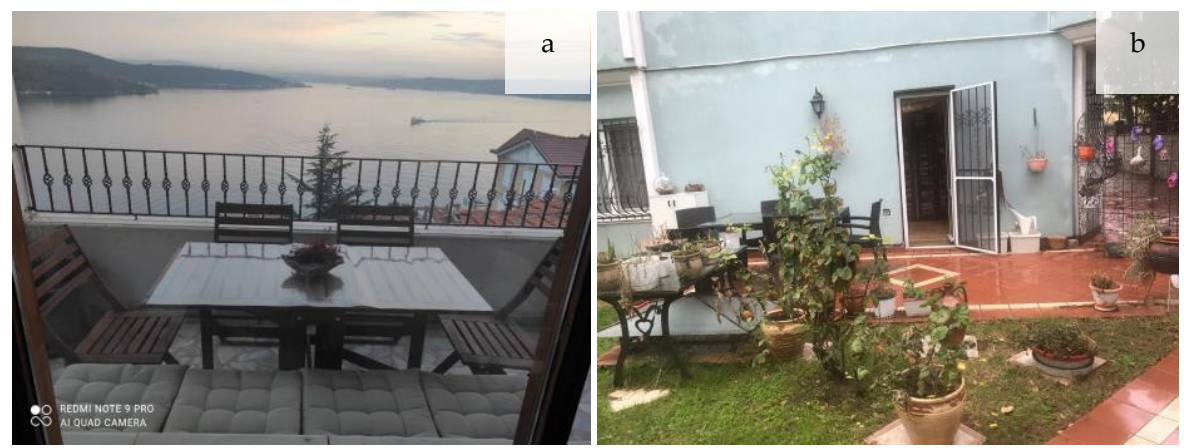

Şekil 10. Olumlu dış-bakı ve dış-dokuya sahip boşluğun değerlendirilmesi ${ }^{12}$

Dış-bakısı işitsel, görsel, kokusal sebeplerle olumsuz algılanan boşluklar ise yedek mekân işlevi görmeye devam etmekte ve pandemi döneminde artan arayüz ve açı alan ihtiyacına rağmen kullanılmamaktadır (Şekil 11).
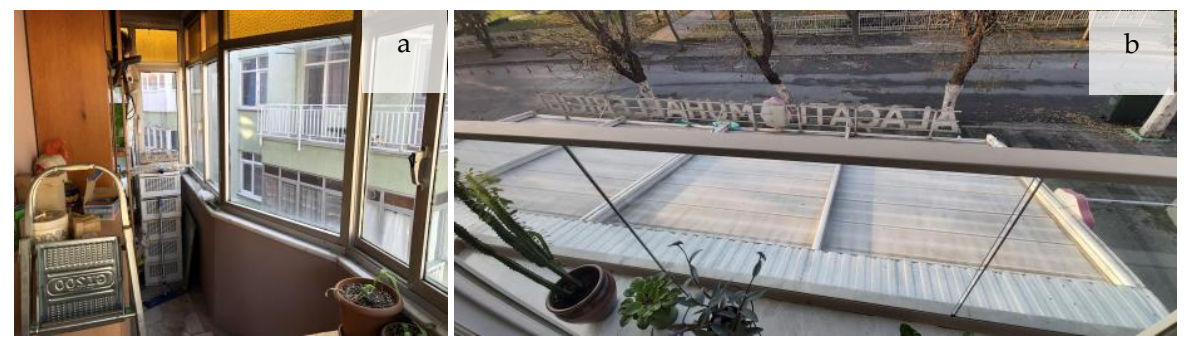

Şekil 11. Dış-bakısı sınırlı ve kesintiye uğrayan arayüzler ${ }^{13}$

Dış-bakısı olan fakat iç-dış olarak net olarak sınırlandırılmamış alanlar ise kullanıcılar tarafından dönüştürülerek daha tanımlı mekânlara bölünmüştür. Bu bölünme, içeriyle kontrollü etkileşime sahip ve dışarıyla ilişki kurabilecekleri mekânlar elde etmelerini sağlamıştır (Şekil 12).

Cam mekân köş, e normalde açık bir köşeydi. Normalde işe gidiyorken salon o kadar kullanılmıyordu. Şimdi pandemiden dolayı ev her şey olduğu için o köşeye paravan gibi bir perde indirdik ve o camekân köşenin kendine özerk bir alan olabilme potansiyeli oluştu. Bu şekilde adaptasyonlar var. ... Oda değil ama küçük bir köşe ve içeriyi görmeyi engelleyecekti. O mekânı evden ayıracak küçük bir perde gibi bir şey indi aslında. ... Burası aslında koyduğumuz paravan sayesinde balkon özelliği taşıyor, kış bahç̧esi

\footnotetext{
12 a: Katılımcı Z-2, Kadın, 35: Dış-bakının değerlendirildiği teras b: Katılımcı F-5, Kadın, 55: Çalışma odasından bahçeye açılan boşluk ve düzenlemesi ${ }^{13}$ a: Katılımcı H-1, Erkek, 41: Kullanıcı tarafından daha önceden kapatılmış salon balkonu b: Katılımcı C-1, Kadın, 42: Salon balkonunun dış-bakı ile ilişkisinin kesintiye uğraması
} 
gibi. ... Paravan için de belki daha kaliteli, yerden yükselen bir paravan tercih edebilirdik. Ev bizim olmadığı için bu tarz bir şey tercih etmedik. (Katılımcı T-2, Erkek, 26) (Şekil 12)
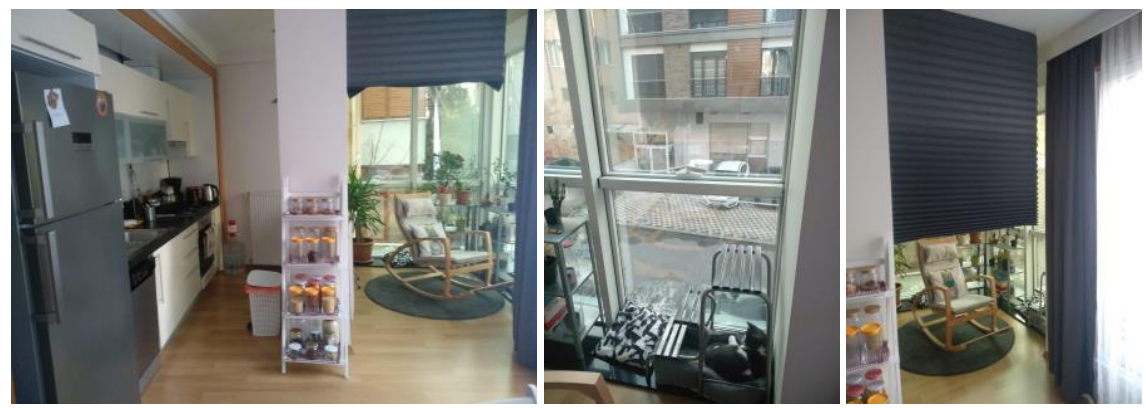

Şekil 12. Dış mekânla temas sınırlandırıcı bitki ve iç mekânla temas sınırlandırıcı paravan: iç mekânın balkona dönüşümü. ${ }^{14}$

Katılımcılardan edinilen bu görüşler doğrultusunda meskene ait boşluk arayüzlere duyulan ihtiyaç tespit edilmiştir. Kullanıcı, mesken içerisinde ışı̆̆a, açık alana ve görsel açıdan tatmin edici bir temasa ihtiyaç duymaktadır. Mahremiyet, iç-dış arasındaki bu etkileşimde önemli bir yer tutmaktadır.

\section{Yakın(sama): Dönüşen dış mekân ve yakın kentsel çevre algısı}

Pandemi döneminde kentsel kamusal mekânlara erişimin, kamusal mekânlarda kullanım ve varoluş biçimlerinin kısıtlanması ve kimi zaman tamamen yasaklanması sebebiyle, mesken yakın çevresinde olan ve kolay erişilebilir açık alanlar, parklar gibi kamusal mekânlar ile daha önce baypas edilen ve kullanılmayan yeni rotalar, yürüyüş ve alışveriş gibi amaçlarla kullanılmaya başlanmış, böylelikle yeni keşiflere olanak sağlamıştır. Kullanıcılar, gündelik hayat pratiklerinde fiziksel olarak keşfettikleri mesken yakın çevresini algısal olarak yakınsamıştır.

Keşfettiğim; Celal Bayar'ın siyasi konuşmalarda çok geçen bir köşkü var, ona rastladım. Şimdi orası bana röper oldu, aradan gidip Celal Bayar Köşk'ünden -çok büyük bir köşk, bahçesinde vârisleri büyük bir apartman dikmişler, köşk bir köşede kalmışçıkıyordum. Yürüyüş aksımda değildi, çünkü ya sahilden yürüyordum ya da Bă̆dat Caddesi'nden yürüyordum. Aralardan geçerken Celal Bayar Köşkü'ne rast geldim. Ama apartman var arkasında, çok büyük dikmişler, öyle şeylere de rastlıyorum. (Katılımcı B-3, Erkek, 67) (Şekil 13)

${ }^{14}$ Katılımcı T-2, Erkek, 26: "Balkon olamamış balkon ve mutfak" 


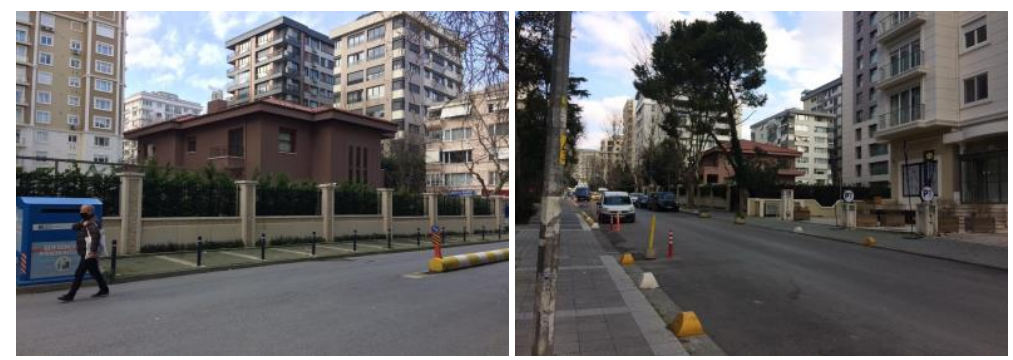

Şekil 13. Yakınsanan yakın çevre ve keşifler. ${ }^{15}$

Kamusal açık alanların kullanımının yasaklandığı zamanlar ya da gruplar için apartman otoparkları, çardaklar ve site içi alanların yürüyüş amaçlı ya da ortaklarla açık hava ihtiyacının karşılanması amacıyla kullanıldığı (Şekil 14) anlaşılmaktadır. Bu alanlar ile ilgili kullanıcıların anlamsal seviyede eylemlere yükledikleri kullanım kodları (hangi eylemin nerede ve kim tarafından gerçekleştirileceğine dair) baskın bir belirleyici olduğu görülmektedir. Bu durum, arayüz tasarımı açısından fakir bırakılmış kent ve binaların kullanıcılarda eylemleri ile ilgili katı ve esnek olmayan fizik-mekânsal uyarlamalar yapmalarına sebebiyet vermekte olduğuna bir örnek teşkil etmektedir.

... Maltepe sahilinde parka sandalye atıp çekirdek yiyip kola veya bira içmeyi tercih ederim. O yüzden o çardakta oturmayı çok tercih etmedim bugüne kadar. (Katılımcı H-1, Erkek, 41) (Şekil 14b)

En uç tarafinda bir yere çardak koymuş durumdalar. Ama ben hiç kullanmadım. Ama apartmanda oturan bazı yaşlılar ara ara oraya iniyorlar, görüyorum. (Katılımcı C-2, Erkek, 32) (Şekil 14c)
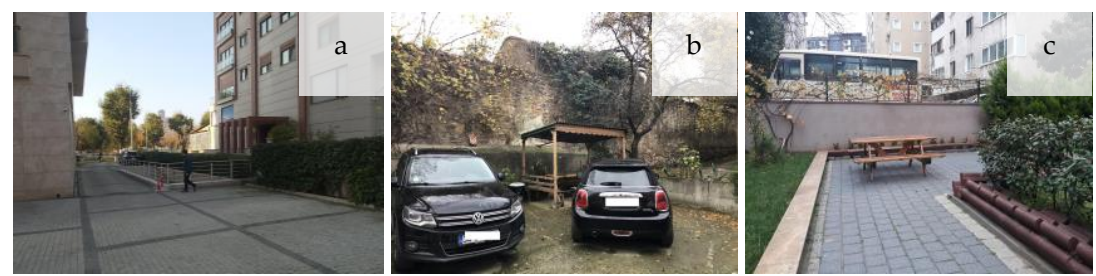

Şekil 14. Sokağa çıma yasaklarında yürüyüş - oturma amaçlı kullanılan otopark. ${ }^{16}$

Daha uzak mesafedeki büyük kamusal mekânlara erişimin kısıtlandı̆̆ durumlarda, yakın çevresiyle teması artıran kullanıcılar, gündelik hayatlarında yakın çevrelerinde bu tip kamusal açı mekânlara ihtiyaç duyduklarını

\footnotetext{
${ }^{15}$ Katılımcı B-3, Erkek, 67: Katılımcının yakın çevresinde keşfettiği yerler.

${ }^{16}$ a: Katılımcı C-1, Kadın, 42: Apartman otoparkında yürüyüş

b: Katılımcı H-1, Erkek, 41: Apartmana ait çardak

c: Katılımcı C-2, Erkek, 32: Apartmana ait çardak
} 
fark etmişlerdir. Meskûn alanların yakın çevresinde kamusal mekâna geçişi kolaylaştıracak, küçük ölçekli olsa dahi kamusal mekan kurgusunun ve ağının işlevsel ve biçimsel bir parçasını oluşturan açı/yarı-açık mekânların tasarlanmasının önemi ortaya çımaktadır.

\section{Evsel arayüz: İçeriye sızan kamusal eylemler}

Mahrem eylem, ifşa etmeme hakkının baki kaldığı eylem türüne işaret ederken kamusal eylem, çeşitli medya (bugünkü koşullarda daha da öne çıkan sosyal medya, konumsal medya, internet, forumlar, podcast yayinlar ve geleneksel kapsamıla radyo, televizyon, basılı medya gibi) aracılığıyla ve "teşhir" yoluyla eylem ve ilişkilerin (sosyal ya da fiziksel) kamu alanına (public domain) getirilmesini içerir (Bauman, 2019). Arendt (1994), kamusal alanı, konuşmanın ve eylemin sergilendiği bir sahne olarak tarif eder; burada birbirini anlayabilen eşitler ve kendilerini anlaşılır kılabilmek için konuşan ve eyleme geçenler bulunur. Bu tanımdan hareketle, kamusal eylemin tarifi, çağın teknolojik olanakları ve bireyin kendisine eşit ve farklılardan oluşan toplum/topluluk içerisinde ve/ya özel mekânda gerçekleştirebildikleri düşünüldüğünde, oldukça zorlaşmaktadır. Herhangi bir eylemi gerçekleştiren kişinin, o eylemi hangi koşullarda (iç ya da dış, özel-mahrem ya da kamusal mekânda, yalnız/tanıdık başkaları ya da tanışıklık olmayan başkalarının eşliğinde/varlı̆̆ında gibi) gerçekleştirmeyi tercih ettiği, kişinin gündelik yaşamda benliğini sunuşuna dahildir (Goffmann, 2016). Bu sebeple, çalışma, eğitim, spor gibi gündelik pratiklerin kamusal eylemler olduğuna dair genelleme yapmaktan kaçınılması gerekliliği göz önünde bulundurularak, bu bölümde, "kamusal eylemler" olarak işaret edilenler, kişilerin pandemi öncesinde konut dışı mekânda, topluluk içinde gerçekleştirmeyi tercih ettikleri ve bu süreçte mesken içine ve kamusal mekâna açılan arayüzlere yakın iç mekânlara taşınmış eylemlerdir. Gerek mekansal yetersizlik gerek bu eylemlerin dış mekânda gerçekleştirilmek istenmesi ya da bu eylemler için özelleştirilmiş mesken dışı açı//kapalı mekânların varlığı gibi sebeplerden dolayı pandemi öncesinde evin içerisinde gerçekleştiril(e)meyen bazı eylemler de evin arayüzlerine taşınmak durumunda kalmıştır. Bu eylemler, mevcut icra edilişleri ile kamuya dair/ait bir mekân oluşumuna sebebiyet vermez, fakat gerçekleştirildikleri mekânı (kullanıcının izin verdiği ölçüde) kamuya açık ve görünür hale getirme potansiyeline sahiptir. Mahremiyet ile özdeşleştirilen meskenin görünürlük, görsel ve işitsel olarak erişilebilirlik bağlamında sınırları bu eylemler aracılığıyla zorlanır. Bu dönemde, diğer kimseler ile temas kurulmasını, yüz yüze iletişimi ve dolayısıyla ortaklaşa bir mekânı gerektiren 
ve aslında günümüz kentinde bir nevi kamusal mekâna açılımı gerektiren çalışma odaklı eylemler de ev içine taşınmak durumunda kalmıştır. Katılımcılar, kamusal alanda ve topluluk ile gerçekleştirdikleri bu eylemleri, konuta taşıdıklarında mesken, kamusal bir işlev yüklenmeye başlar. Çalışma alanına dönüştürülen mekânlar, genellikle mesken içi kamusallık seviyesi en yüksek olan salon olmuştur. Bu durum, meskende yedek mekâna sahip olmalarına rağmen, kullanıcıların eylemler ve meskendeki alanların kamusallık seviyeleri ile anlamsal boyutta yaptıkları ilişkilendirme ile alakalı gözükmektedir (Şekil 15).
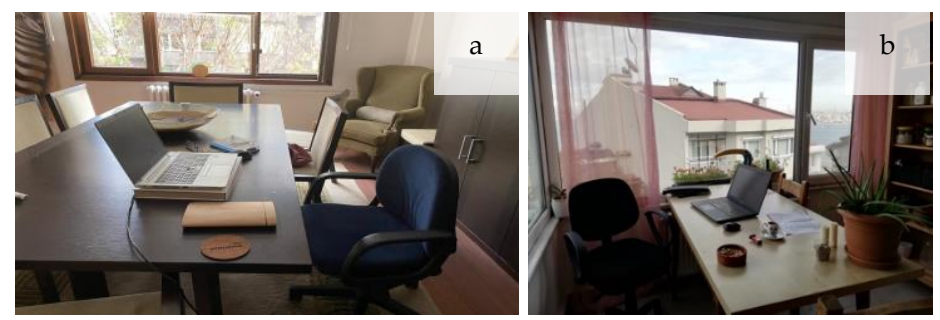

Şekil 15. Eylemin kamusallık seviyesine göre tercih edilen mekân ${ }^{17}$

Yedek mekânın olmadığı ve hanehalkı bireylerinin farklı işlevleri eş zamanlı yerine getirmesi gereken durumlarda ise mekânın bölümlenmesi, yeniden düzenlenmesi üzerinden kişisel eyleme ait mekânlar fiziksel ya da algısal olarak birbirinden ayrıştıılmaya çalışılmaktadır. Bu noktada kişisel uyumlanma stratejilerinin mekândaki uyarlama seviyesinden daha baskın olduğu gözlemlenmektedir (Şekil 16).
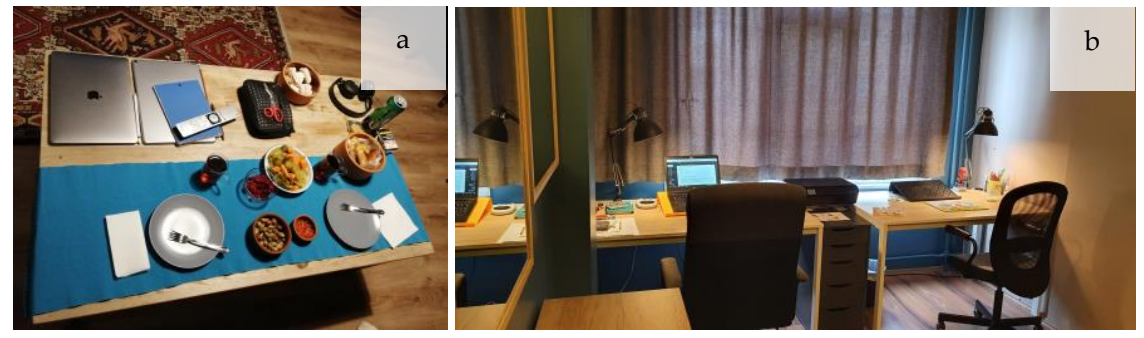

Şekil 16. Çakışan farklı eylemler. ${ }^{18}$

\footnotetext{
17 a: Katılımcı Z-3, Kadın, 35

b: Katılımc1 L-2, Kadın, 37

18 a: Katılımcı L-2, Kadın, 37: Yemek ve çalışmanın kesişimi

b: Katılımcı S-2, Erkek, 34: İki çalışanın yedek mekânsız bir meskende kesişimi
} 
Çalışma ve eğitim alma gibi zorunlu eylemler ile benzer biçimde uzaktan yapılan hekim görüşmeleri, terapiler ve katılım gösterilen kurslar, konferanslar ve tiyatro oyunları da kişilerin mesken içinde kamusal bir eylemi deneyimlemelerine olanak tanımıştır. Bu eylemler her ne kadar kamusal mekân üretimine katkı sağlamasa da katılımcıların bu dönemde gerçekleştirdikleri uyumlanma odağında sıklıkla bahsedilmektedir. Bu eylemler için seçilen mekânın arayüz niteliği, kamusal eylemin mekânsal geçişkenliğini de gösterir niteliktedir. Meskenin dışarıya açılan arayüzlerinden, dış-bakıya sahip olmanın değil dış-dokuya uzamsal olarak yaklaşmanın tercih edildiği görülen bu mekân tercihleri, meskenin içerisinde kullanıcı tarafından farklı kamusallık ilişkilendirmeleri ve kodlamaları yaptığına işaret etmektedir. Örneğin, balkonu olan bir meskende, yedek mekâna, siteye ait ortak yürüyüş parkurları ve açık ve kapalı spor alanları olan B-1, dışarı çıkamadığı zamanlarda "antrede mat ve dumbıllar ile spor yapabil[diğini], [bu mekânın] temel hareketleri yapmak için yeterli bir alan" olduğunu belirtmektedir. Bu mekân, meskenden dışarısının izlendiği değil, dışarıya çıkmak için kullanılan bir arayüz olarak düşünüldüğünde, evin dışında da "kapalı" alanda gerçekleştirilebilecek bu eylemin antrede gerçekleştiriliyor oluşuna dair eylemlere ve mekânlara kullanıcılar tarafından atfedilen kodlara dair anlambilimsel seviyede bir örnek teşkil etmektedir (Şekil 17).
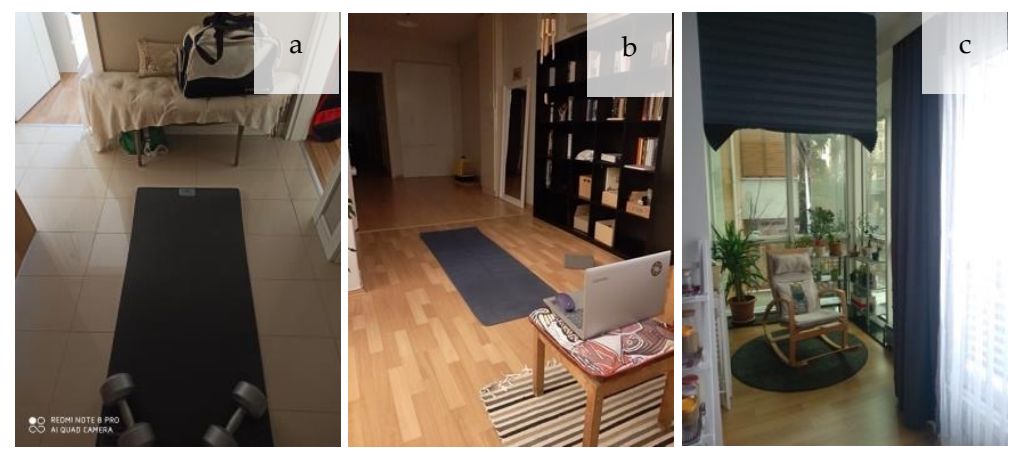

Şekil 17: Eylem ve mekânın anlamsal ilişkilendirilmesi ${ }^{19}$

\footnotetext{
${ }^{19}$ a: Katılımcı B-1, Erkek, 34: Antrede yaratılan spor alanı.

b: Katılımcı S-1, Kadın, 38: "Antre anlamsız büyük. Spor alanı olarak kullanmaya başladım." c: Katılımcı T-2, Erkek, 26: "Balkon olamamış balkon ve mutfak."
} 


\section{Kamusal arayüz: Dışarıya taşan özel eylemler}

Bağımsız birime giriş mekânları kamusal mekâna uzanan ilk temas noktası olarak ele alınırken, pandemi döneminde bu algı güçlenmiş ve bu mekânların kamusal niteliği öne çıkmıştır. Özellikle bu dönemde ehemmiyet gösterilen hijyen ihtiyacı doğrultusunda alınan bireysel önlem uygulamalarının, kimi konutlarda yukarıda bahsedilen türde boşluk arayüzlerinin eksikliği ve/veya giriş mekânlarının yetersizliği, küçüklüğü veya tanımsızlı̆̆ı sebebiyle meskenin dış mekânına doğru kaydığı anlaşılmıştır. Ev içi kullanıma sığdırllamayan veya hijyen, havalandırma gibi gerekçelerle bu mekânlara taşma ve meskene ait eşyaların konumlandırlışı, meskenin kamusal mekân ile ve kullanıcının da hanedışı ortaklar ile buluşma noktasını tanımlar hale gelmiştir.

Dolayısıyla mesken içinde bu geçişin tanımsız olduğu, antresiz, koridorsuz ve doğrudan yaşama alanına açılan mesken kurgusu, kullanıcıların özel ve kamusal arasındaki geçişte yaşanan eylemsel kaymalarla birlikte meskenin pandemi koşullarına göre esnetilmesini/genişletilmesini/taşmasını beraberinde getirmiştir (Şekil 18).

Evimin girişi zaten dardı. Pandemide burası kargo, market poşetleri ve su şişesi gibi şeylerin eve girmeden dezenfekte edildiği ve beklettiğim alan oldu. Bu beni çok zorladı. Zaten dar olan alan, daha da daraldı. (Katılımcı Z-1, Kadın, 43) (Şekil 18b)

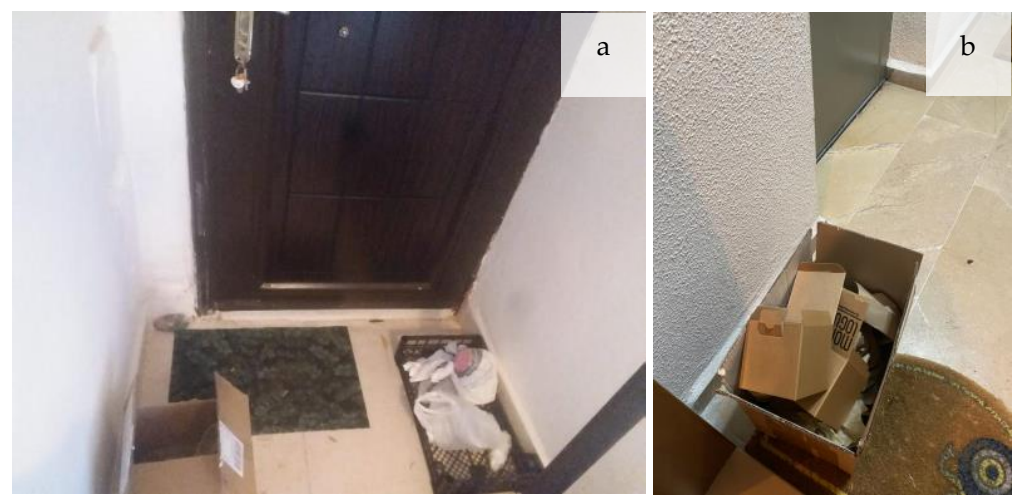

Şekil 18. Giriş mekânının yetersizliği sebebiyle dış mekâna taşan kullanım..$^{20}$

Bu kaymalar, mesken kullanıcısının apartman ortakları başta olmak üzere kamusal alana geçiş yaptığı arayüzleri, kullanıcının hem dış hem iç mekân kullanımını hem de gündelik hayat alışkanlıklarını etkileyecek şekilde dönüştürmektedir. Bu durumun sebebi, bu temas noktalarının yetersizliği ve

\footnotetext{
${ }^{20}$ a: Katılımcı Z-1, Kadın, 43

b: Katılımcı Z-3, Kadın, 35
} 
zaman içerisinde tasarım şablonlarında göz ardı edilebilir mekânlar kategorisine alınmış olmalarıdır. Bu mekânlar genelde özel alanın sınırı olarak ele alınıp iç-dış ve özel-mahrem geçişleri ve kullanımları gözetilmeden tasarlanmaktadır. Kamusal arayüzlerin de meskenin kamusal temasa geçiş arayüzlerinden biri olarak değerlendirilmesi ve bu geçişken alanda kullanıcının ihtiyaçları gözetilerek tasarlanması önemlidir.

\section{Yedek mekânlar}

Meskenin fonksiyonel bölümlenmesinde artık kalan, gündelik yaşamsal değeri olmayan ve depolama gibi ihtiyaçların giderilebildiği giysi odası, misafir odası benzeri sürekli kullanıma açık olmayan yedek mekânları olan kullanıcılar, bu alanları ortaklar ile eş zamanlı gerçekleştirmeleri gereken ve esasen mesken dışında bir mekânda gerçekleştirmeye alışkın oldukları eylemler için uyarlamıştır. Bunu yaparken bu mekânı tamamen dönüştürmeyi ve bu şekilde kullanımının sürekliliğinin öngörülmediği durumlarda mevcut taşınabilir mobilyaların yeniden düzenlenmesi ile mekânda fonksiyonel farkl1laşmaya gidilmektedir. Örneğin katılımcı B1, "daha önce balkonda duran masa ve sandalyeyi giyinme odasına taşıyarak, [pencere] kenarında bir çalışma ortamı" oluşturduğunu anlatmakta, katılımcı L-2 ise "eskiden yatak odası olan yer, çalışma odası-yedek oda oldu. Salondaki kitaplık buraya taşındı" şeklinde mesken içerisindeki yedek mekân kullanımını anlatmaktadır (Şekil 19).
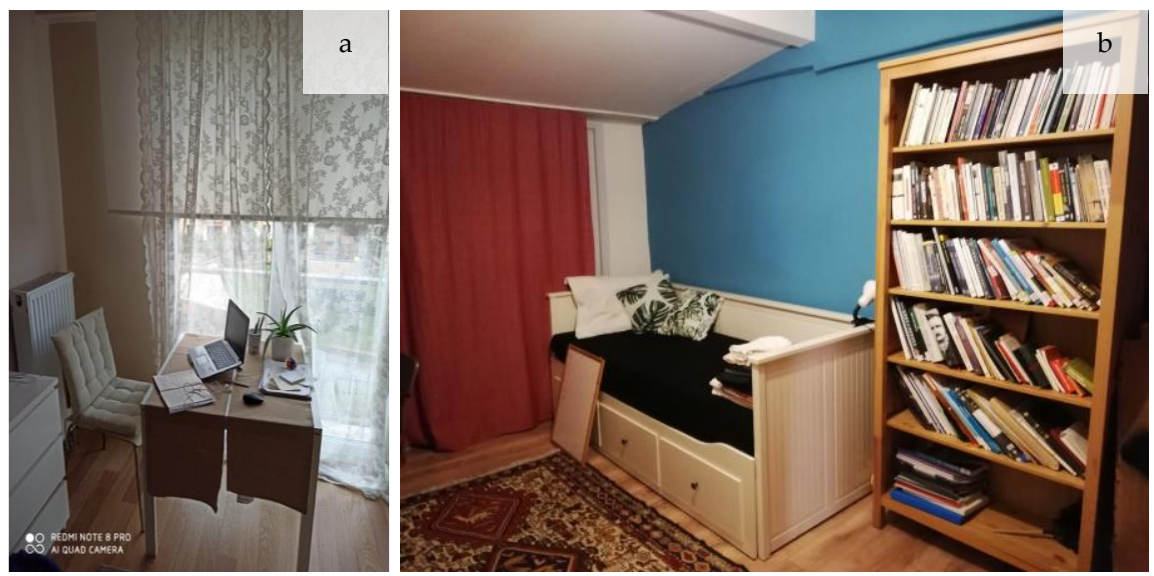

Şekil 19. Yedek mekân uyarlamasi²1

${ }^{21}$ a: Katılımcı B-1, Erkek, 34

b: Katılımc1 L-2, Kadın, 37 
Yedek mekân, meskende daha çok vakit geçirilen ve hanehalkı bireylerinin eş zamanlı ve tanımlı kişisel sınırlara ihtiyaç duyduklarında fizik mekânsal ve psikolojik olarak önemli bir rahatlatıcı etmen olmuştur. Yapılaşma örneklerinde her bir kullanıcı için "asgari ancak yeterli, bağımsız ve yaşanabilir bir oda" (Teige, 1932) önerisindekine benzer nitelikteki minimalist trendin aksine, yeterli, bağımsız, bölünebilir ve esnetilebilir mekânın bireyselliğe, mahremiyete ve farklı eylemlerin ardıl ve/veya eş zamanlı gerçekleştirilebilmesine olanak verecek bir tasarım kurgusu önceliklenmelidir.

\section{Genel Değerlendirme ve Sonuç}

Tüberküloz modernizmi şekillendirirken (Colomina, 2019), veba ve kolera gibi salgınlar modern kentsel altyapı ve planlamanın tetikleyicisi olmuştur. COVID-19 pandemisini de özel (mahrem) mekânlar olan ve arayüzler üzerinden kentsel mekân ile etkileşim kuran mesken yaşamını etkilemektedir. Bu salgının beraberinde gelen "sosyal mesafe" ve içeride kalmaya dair kolektif kullanıc deneyimleri de muhakkak mimarlık ve planlama disiplinlerinin yakın geleceğini etkileyecektir. Mesken özelinde, bahsedilen etkiyi anlamlandırmada kullanıcıların ihtiyaç ve deneyimlerinin rolü büyüktür. Bu sebeple, çalışma kapsamında, kullanıcı ve eylemleri doğrultusunda gerçekleştirdiği müdahaleler odağa alınmıştır. Gönüllü katılımcılar ile yapılan derinlemesine görüşmeler için kullanıcının (1) mekân ile ilişkisi, (2) kullanıcıyı tanımlayan eylemler ve (3) mesken içi ve dışı ortaklar odağında açık uçlu bir soru şablonu oluşturulmuştur. Görüşmelerde pandemi süreci öncesi "kullanıcının yaşantısına ve mekân kullanımı"na ardından da pandemi sonrası gelişen yeni ihtiyaçlara göre gerçekleştirdiği "mekân değişiklikleri, uyumlanma ve uyarlamalar" ile ilgili sorular, karşılaştırma yapmaya olanak verecek şekilde tasarlanmıştır.

Meskende geçirilen zamanın ve buna paralel olarak bu mekânda gerçekleştirilen eylemlerin çeşitliliğinin artması, meskenin kimi eylemler için yetersiz kalmasına sebep olmuştur. Kimi kullanıcılar bu yetersizliği gidermek için mekânı uyarlamış, kimi kullanıcılar ise çeşitli sebeplerle mekânı uyarla(ya)mayıp kendini mekâna uyumlandırmıştır. Bu çerçevede mesken içi mekân kullanımları değişmiş, kullanıcının kente, yakın çevreye ve meskene dair algısında değişiklikler meydana gelmiştir. Meskende, çoğu zaman ortaklarla bu kadar uzun zaman geçirmek ise, daha önce fark edilmeyen, dikkate alınmayan hususlara dair farkındalığın gelişmesine sebep olmuştur. Bu farkındalık ise sadece fonksiyonel yetersizlikler üzerinden değil, ayn zamanda geçirilen zamanın kalitesi açısından da tanımlanmıştır. 
Çalışmanın ortaya koyduğu üzere, özel mekândaki eylemler üzerinden anlamlandırılan mesken, kullanıcılar açısından içinde güvenli bir biçimde yaşamsal faaliyetlerini gerçekleştirdikleri yer olmanın yanı sıra, arayüzler arac1lığıyla kent ve kamusal olan ile fiziksel, görsel etkileşime girilebilen bir mekân olarak da tariflenmeye başlamıştır. Meskenin kazandığı yeni tür bir kamusallık, mesken ve kamusal mekân etkileşiminin kurulduğu arayüzlerde işlevsel ve anlamsal kaymalara neden olmuştur.

Bu mekânsal kaymalar (1) kamusal mekânla fiziksel ve görsel temasın sağlandığı karşılaşma noktaları olarak dış-bakı / dış-doku, (2) kullanıcının açık alan ihtiyacından doğan verili-tasarlanmıştaki kullanım değişimin sebebi olan boşluk tasarımı, (3) dönüşen diş mekân ve yakın kentsel çevre alg1sına odaklanan yakın(sama), (4) dışarıya atfedilen eylemlerin iç mekânda gerçekleştirilmesinin tercih edildiği kullanım kaymalarına olanak veren evsel arayüz, (5) içeriye atfedilen eylemlerin dış mekâna taşarak eylemin kamusallık seviyesinin yükselmesine olanak veren kamusal arayüz ve (6) meskenin fonksiyonel bölümlenmesinde artık kalan, gündelik yaşamsal değeri olmayan ve depolama gibi ihtiyaçların giderilebildiği yedek mekânlar altında kategorize edilmiştir. Bu kategorizasyon, mekânsal arayüzün teorik tarifini genişletme yönünde veri sağlamıştır. Arayüzün meskenin ve kentsel kamusal alan ile temasının sınır olarak tariflenmesindense, karşılaşma, dönüşme ve eklemlenme mekânları olarak düşünülmesi gerekliliği ortaya çıkmıştır. Bu bağlamda arayüz, kamusal-özel, iç-dış, kapalı-açık fark etmeksizin mekânların fiziksel, görsel, eylemsel açıdan birbirine eklemlendiği, fiziksel niteliklerin, eylemlerin ve kullanıcıların karşılaşıp, dönüştüğü mekânlardır.

Bu tanımlamayla "kullanıcıların deneyim ve tepkilerinin tasarım girdisine dönüşümü" açısından farkındalık ve başlangıç seviyesinde veriler elde edilmiştir. Verili-tasarlanmışın yetersiz kaldığı noktalarda kullanıcıların uyarlamaları, bu mekânlarla ilgili yeniden düşünülmesi gereken tasarım kriterlerine dair ipuçlarını göz önüne sermektedir. Bu çerçevede, arayüzlerin mahremiyetin sağlanmasına ek olarak, görsel etkileşim ihtiyaçları gözetilerek tasarlanması gerekliliğine dair kullanıc ihtiyaçları gözlenmiştir. İç mekân gereksinimlerini gözeten bir kurguya dayanan, komşu mekânlar ve yakın çevredeki fiziksel oluşumları dikkate alan boşlukların ve yapı formundaki hareketlerin önemi ön plana çıkmaktadır. Geçiş alanlarına dair aktarılan fiziksel ihtiyaçlar göz önünde bulundurulduğunda ise, mesken iç ve dış mekân geçişlerinin, keskin ve ayrıştırıc bir yüzey olarak düşünülmesinden ziyade uyarlanabilir ara mekânlar olarak tasarlanmasının gerekliliği ortaya çıkmaktadır. Tüm bu tespit ve öneriler özel ile kamusalın arakesitinde olan arayüzün 
kullanıcları ve eylemlerini dikkate alan ve mimarlık ile planlama disiplinlerinin ölçeklerarası bir yaklaşımını gerektirdiğini göstermektedir.

Bu tespitlere ek olarak, günümüz yaşantısının ve pandeminin getirdiği mecburiyetler ile değişen mesken içi eylemlerin çeşitliliği, kullanıcıların uyum ve uyarlamalarına olanak verecek bir "esneklik" kurgusuna ihtiyacı doğurmaktadır. Kullanıcıların, tek işlevi olan kapalı özel mekân alanını maksimize etmeye odaklı nicelik-öncelikli tasarım kurgusundan ziyade esnek, uyum ve uyarlamalara açık mekân tasarımlarına gereksinim duydukları aşikârdır. Bu ise ancak olası farklı kullanım senaryolarına açık, kullanıcıyı önceleyen, tasarım sürecine katan ve kullanıcı eylemlerinin tasarım kriterlerini belirlediği bir yaklaşımla mümkün olacaktır.

Kullanıcı deneyimlerinden elde edilen veriler doğrultusunda, arayüzlerin, kullanıcıları kamusal alana davet edecek nitelikte tasarlanması önemli gözükmektedir. Bunun için yine meskenden dışarıya ve ortak kullanım ve eylemlere ev sahipliği yapabilecek ya da iç mekânla ilişkili eylemlerin diş mekânlara doğru genişlemesine olanak sağlayacak mesken-kamusal alan uzamında tasarım kurgusuna ihtiyaç olduğu muhakkaktır.

Kullanıcıyı ve arayüz kavramını odağına alan araştırma kurgusu, mevcut durumda kullanıcı ihtiyaçlarını, uyarlama ve uyumlanma stratejilerini değerlendirmeyi hedeflemiştir. Bu çalışmadan elde edilen ipuçları ise mimarlık ve planlama pratisyenlerine önemli öngörü sağlayacağı gibi, yeni keşifler ve küçük ölçekli deneyler seviyesinde kalacak kullanıcı müdahaleleri ile özel alan sınırları içerisinde "taktik şehircilik" (tactical urbanism) kapsamını çağrıştıran, yani aşağıdan yukarıya gerçekleştirilen tasarım pratiğinin mümkün olabileceğini göstermiştir. Kentin farklı sosyo-ekonomik ve sosyo-kültürel sınıflarının yaşadığı, farklı yoğunluklara ve farklı baskın mesken tipolojilerine sahip alanlarında, kentsel kamusal alan ile mesken arayüzlerinin tasarımları ölçekler ve disiplinlerarası bir vizyon ve uyum içerisinde gerçekleştirildiğinde, mesken artık duvarlarla sınırlanan bir mekân olmaktan çıkacak; kent, kentlisine ve kentlinin ihtiyaçlarına alternatifler sunabilen bir yuva haline gelecektir 


\section{Extended Abstract}

\section{Spatial Shifts in the Context of Crisis: Changing Definitions of Interface via User Experiences}

\author{
Melis Ŏguz \\ ORCID: 0000-0002-1837-4356
}

*

Aslı Uzunkaya

ORCID: 0000-0002-4120-7839

Throughout history, epidemics have played a major role in the shaping of cities and architecture, but for the first time, during the COVID-19 pandemic, the dwelling and its borders have come to the fore as a sheltered place. In such a context, this study focusing on the physical and perceptual relationship and contact between the dwelling and its immediate surrounding takes interfaces as the primary parameter to detect this relationship. In the research, the aim has been to answer following questions: (1) How did COVID-19 pandemic affect the life of the citizens at residential scale? (2) What is the role of the user in the formation and transformation of spatial interfaces? (3) Do the users' experiences and reactions turn into design input? Based on participants' responses, the researchers try to re-define private and public space as well as the interface. In line with these goals, the theoretical framework of the study emphasizes both the conceptualization of interface and the role of the user in design studies.

The interfaces are considered as the transition areas between private and public spaces, that is, the intersection areas where the interior and exterior of a building meet. However, a clear definition of which standards constitute a "public" or "private" space would inevitably ignore the complexity that lies at the heart of research into the spatiality of publicness and privateness. Thus, a re-definition of public space, private space and the interface requires interdisciplinary interaction, cross-scale thinking and mixed-research method putting the user into the forefront. Studies that focus on the user can generally be categorized as (1) evaluations of the design process with the participation of the user, (2) artistic/performative studies where the user plays a role in decision-making mechanisms, and (3) post-occupancy evaluations. In post-occupancy evaluations, the user is 
seen as the converter of what is imposed on them by design. Structures have a character determined by patterns of events that are and continue to be there. The user rearranges the space as an alternative to what they cannot access through indoor-outdoor spaces where they perform their every-day life rituals.

In this study, user rituals and experiences were taken as a basis. The research was designed as a "field" where transparency and trust are ensured between the researcher and the participants, where the researchers take the participants as a part, shaper, and transformer of the research setup. In-depth interviews were conducted with 24 participants differing in age, gender, household size and structure, dwelling and settlement typologies. The interviews focused on (1) life and spatial use of participants (2) spatial changes and adaptations regarding (a) the dwelling and the surrounding public space, (b) actions, and (c) commons. An ethnographic research process was carried out between December 2020 and January 2021. Due to the COVID-19 measures, in-depth interviews with the participants were carried out via online platforms, and these interviews were recorded with the consent of the participants. To exemplify and document the narratives of the participants, photographs of the dwellings, the surrounding public spaces, their adaptations in these spaces were requested. The participants shared their photographs on an online board-platform, which was accessible to all the participants of the research turning this experience into a focus group study-like environment. To understand the differing experiences of the participants, representation of different types of housing typology within various urban morphologies has been favoured.

As the study reveals, the increase in time spent and the diversity of the actions performed in the dwelling have resulted in the dwelling to be perceived as insufficient. The interfaces, which were observed to be ignored by both the designer and the user, caused the weakening of the relationship established with the immediate external environment of the dwelling. The insufficiencies of the inner and outer spaces and interfaces lead users to make adaptations on their use and/or on the spaces resulting in spatial shifts of user actions. These spatial shifts revealed by research findings have been evaluated in six different categories:

(1) Exterior-look / exterior-texture: Encounter points where physical and visual contact with the public space is provided

(2) Void design: Change of use in the ascribed-designed arising from the user's need for open space

(3) Converge(nce): Transforming perception on outdoors and surrounding urban environment 
(4) Domestic interface: The Interface that allows the the actions attributed to the exterior to be performed indoors

(5) Public interface: The interface that allows the actions attributed to the interior to expand to the exterior, increasing the level of publicity of the action.

(6) Spare spaces: Spaces that no longer have a daily life value in the functional division of the dwelling, but where needs such as storage can be met.

Owing to the findings of the research, it can be argued that there is need for a design setup that allows the expansion of indoor-related actions towards outdoor spaces and vice versa. The dwelling has been given meaning through the actions in the private space. Yet, it has begun to be re-defined as a place where physical and visual interaction with the city and the public can be made through interfaces. It is now functioning as a place where users safely perform their vital activities. The diversity of indoor actions, changing with the pandemic conditions and the advancements in technology, creates the need for a flexible design setup that will allow users to adapt and transform.

\section{Kaynakça/References}

Alexander, C. (1979). The timeless way of building. New York: Oxford University Press. Arendt, H. (1994). İnsanlı durumu (B. S. Sener, Çev.). İstanbul: İletişim.

Bauman, Z. (2019). Akışkan modernite (S. O. Çavuş, Çev.). İstanbul: Can Yayınları.

Benhabib, S. (1992). Situating the self: gender, community and postmodernity in contemporary ethics. New York: Routledge.

Berg, A. (2014). Artistic research in public space: participation in material-based art. Helsinki: Aalto University.

Cohen, J. (1997). Rethinking privacy: autonomy, identity and the abortion controversy. J. Weintraub ve K. Kumar (Ed.), Public and private in thought and practice (s. 133165) içinde. Londra: University of Chicago Press.

Cohen, J. ve Arato, A. (1992). Civil society and political theory. Cambridge: MIT Press.

Colomina, B. (2019). X-Ray architecture. Zürich: Lars Müller Publishers.

Cooper, I. (2001) Post-occupancy evaluation - where are you? Building research \& information, 29(2), 158-163.

Cupers, K. (2013). Use matters: an alternative history of architecture. New York: Routledge.

Dovey, K. ve Wood, S. (2015). Public/private urban interfaces: type, adaptation, assemblage, Journal of Urbanism, 8(1), 1-16.

Gehl, J. (1977) The interface between public \& private territories in residential areas. Melbourne: Melbourne University.

Goffmann, E. (2016). Gündelik yaşamda benliğin sunumu (B. Cezar, Çev.). İstanbul: Metis Yayınları.

Habermas, J. (2003). Kamusallh̆̆ın yapısal dönüşümü (T. Bora ve M. Sancar, Çev.). İstanbul: İletişim Yayınları. 
Jones, P. B., Petrescu, D. ve Till, J. (Ed.) (2005). Architecture and participation. Abingdon: Routledge.

Lefebvre, H. (1991). The production of space (D. Nicholson-Smith, Çev.). Oxford: Blackwell.

Liebman, S. (2004). Alexander Kluge ile söyleşi: yeni Alman sineması, sanat, aydınlanma ve kamusal alan üzerine (N. Dinç ve M.Özbek, Çev.). M. Özbek (Ed.), Kamusal alan (s. 609-651) içinde. İstanbul: Hil Yayın.

Meyrowitz, J. (1985). No sense of place. New York: Oxford University Press.

Mihalache, A. ve Emmons, P. (2013). Architectural handbooks and the user experience. K. Cupers (Ed.). Use matters: an alternative history of architecture (s. 35-50) içinde. Londra: Routledge.

Negt, O. ve Kluge, A. (2004). Kamusal alan ve tecrübeye giriş (M. Özbek, Çev.). M. Özbek (Ed.), Kamusal alan (s. 133-139) içinde. İstanbul: Hil Yayın.

Oğuz, M. ve Uzunkaya, A. (2020, Kasım). Pandemi sürecinde esne(ye)meyen meskenler yet(e)meyen kamusal alanlar [Öz]. 8 Kasım Dünya Şehircilik Günü 44. Kolokyumu'nda (çevrimiçi) sunulan bildiri. Erişim adresi: https://www.youtube.com/watch?v=7FXPm3dvexY.

Porter, T. (2004). Archispeak: an illustrated guide to architectural terms. Londra: Spon Pres.

Sanoff, H. (1999). Community participation methods in design and planning. New York: Wiley.

Sennett, R. (2013). Kamusal insanın çöküşü (S. Durak ve A. Yılmaz, Çev.). İstanbul: Ayrıntı Yayınları.

Sheller, M. ve Urry, J. (2003). Mobile transformations of "public" and "private". Life in theory, culture and society. 20(3), 107-25.

Silva, M.F., Maas, S., Souza, H.A. ve Gomes, A.P. (2017). Postoccupancy evaluation of residential buildings. Luxembourg with centralized and decentralized ventilation systems, focusing on indoor air quality (IAQ). Assessment by questionnaires and physical measurements. Energy and Buildings. 148, 119-127.

Teige, K. (1932). The minimum dwelling (E. Dluhosch, Çev.). Cambridge: MIT Press.

Vardouli, T. (2015). Making use: attitudes to human-artifact engagements. Design Studies. 41, 137-161.

Zimring, C. ve Reizenstein, J. (1980). Post-occupancy evaluation. Environment and behavior. 12(4), 429-450. 